\title{
Ages of ophiolitic rocks along plate suture in Taiwan orogen: Fate of the South China Sea from subduction to collision
}

\author{
Yun-Chieh Lo ${ }^{1}$, Chih-Tung Chen ${ }^{2, *}$, Ching-Hua Lo ${ }^{1}$, and Sun-Lin Chung ${ }^{1,3}$ \\ ${ }^{1}$ Department of Geosciences, National Taiwan University, Taipei City, Taiwan \\ ${ }^{2}$ Department of Earth Sciences, National Central University, Taoyuan City, Taiwan \\ ${ }^{3}$ Institute of Earth Sciences, Academia Sinica, Taipei City, Taiwan
}

\begin{abstract}
Article history:
Received 25 December 2018

Revised 18 June 2019

Accepted 19 June 2019

Keywords:

Ophiolite, South China Sea, Lichi

Mélange, Yuli Belt, Taiwan

arc-continent collision

Citation:

Lo, Y.-C., C.-T. Chen, C.-H. Lo, and S.-L. Chung, 2020: Ages of ophiolitic rocks along plate suture in Taiwan orogen: Fate of the South China Sea from subduction to collision. Terr. Atmos. Ocean. Sci., 31, 383-402, doi: 10.3319/TAO.2019.06.19.01
\end{abstract}

\begin{abstract}
Ophiolite-bearing belts mark convergent plate suture zones and are central in reconstructing plate configuration and structures of mountain belts. The active Taiwan mountain belt, product of ongoing convergence between the Eurasian and Philippine Sea plates, has dismembered ophiolitic rocks exposed on both sides of the Longitudinal Valley suture: blueschist blocks in schistose Yuli Belt to the west, and the Eastern Taiwan Ophiolite (ETO) in the unmetamorphosed Lichi Mélange to the east. How these ophiolitic materials correlate with the consumed South China Sea and Luzon forearc oceanic lithospheres between the colliding Chinese continental margin and the Luzon Arc remained speculative. We present zircon U-Pb age results from both ophiolitic rocks in the Yuli Belt and the ETO to pinpoint the formation ages of respective oceanic crusts, and ${ }^{40} \mathrm{Ar} /{ }^{39} \mathrm{Ar}$ dates to unravel the tectonothermal history. The zircon U-Pb ages of $\sim 15 \mathrm{Ma}$ for all analyzed samples indicate a common South China Sea origin for ophiolitic materials across the plate suture, since oceanic crust of the Philippine Sea Plate near Taiwan is either Eocene or older. The ${ }^{40} \mathrm{Ar} /{ }^{39} \mathrm{Ar}$ ages of Yuli meta-ophiolitic rocks might suggest blueschist metamorphic overprint at $\sim 9 \mathrm{Ma}$. The ${ }^{40} \mathrm{Ar} /{ }^{39} \mathrm{Ar}$ results are generally identical to zircon $\mathrm{U}-\mathrm{Pb}$ ages for the ETO rocks, concurrent to their olistostromal origin in the forearc basin after being tectonically transported from the trench interface to the eastern retrowedge within the Hengchun accretionary prism. A working tectonic model for the Taiwan arc-continent collision is put forward with emphasis on the fate of the South China Sea during the mountain building processes.
\end{abstract}

\section{INTRODUCTION}

Convergent plate sutures are often marked by ophiolite-bearing belts where entire or partial sections of oceanic lithosphere were consumed during collisional or accretionary orogenesis (e.g., Pan et al. 2012). The type, tectonic settings and paleogeographic origin of the ophiolitic rocks are essential in plate reconstructions of the associated mountain building (e.g., Dilek and Furnes 2014; Xu et al. 2015). As the obducted or exhumed remnants of the intervening oceanic lithosphere, the ophiolite-bearing belts offer invaluable evidences and insights to the subduction processes preceding arc-continent or continent-continent sutures, as well as the deformation and metamorphic overprint during successive

\footnotetext{
* Corresponding author

E-mail: chihtung@ncu.edu.tw
}

orogenic processes (e.g., Ernst 2010; Yui et al. 2014; Malavieille et al. 2016). Therefore, the ophiolite-bearing belts are key components in discerning the overall architecture and evolution of convergent plate boundaries, whereas records of the processes responsible for the emplacement and exhumation of ophiolite-bearing belts are often obscured by later orogenic deformation and erosion. The active mountain building system of Taiwan, with well-constrained tectonic framework (Suppe 1981), serves as a modern model of ophiolite evolution in collisional plate sutures.

The island of Taiwan, located on the ongoing convergent boundary between the Eurasian and the Philippine Sea plates, is the result of collision between the Chinese continental margin and the Luzon Arc (Teng 1990). On land there are three orogen-parallel ophiolite-bearing geologic units: 
the Kenting and Lichi mélanges, and the Yuli Belt (Fig. 1). The Kenting Mélange is an unmetamorphosed subduction mélange exposed in the emerged accretionary prism in the southern tip of the island (Chang et al. 2003). The Lichi Mélange is an unmetamorphosed collisional mélange due to forearc closure, and is exposed along the western border of the accreted arc (Chang et al. 2000; Chen et al. 2017a). The Yuli Belt, previously considered to be the Mesozoic subduction zone of the paleo-Pacific Plate (the "Kula Plate"; Yui et al. 1988), is recently re-interpreted as a blueschistfacies Miocene subduction complex juxtaposed east of the exhumed continental margin basement (Tsai et al. 2013; Yui et al. 2014; Chen et al. 2017b). From initial subduction to final arc-continent collision, two major oceanic domains have been consumed and are the source candidates for ophiolites found in these belts: the South China Sea along the subducting plate interface, and the Philippine Sea Plate oceanic lithosphere in the Luzon forearc region. While the consumption of South China Sea followed by Chinese continental margin subduction along the Manila Trench is well-characterized southwest of Taiwan (Lin et al. 2009), how the South China Sea lithosphere was incorporated into the orogenic system remains largely speculative (e.g., Suppe et al. 1981; Chang et al. 2009; Malavieille et al. 2016; Hsieh et al. 2017). The destruction of the $\sim 100 \mathrm{~km}$-wide Luzon forearc crust is essential in bringing the Luzon Arc to collisional contact with the exhumed continental margin (Lu and Hsu 1992; Shyu et al. 2005); tectonic erosion through underthrusting beneath the arc is the currently favored mechanism (Chang et al. 2001; Shyu et al. 2011; Chen et al. 2017a). Of the Taiwan ophiolite-bearing belts, only the Kenting Mélange was the direct product of South China Sea subduction and the ophiolitic rocks within are mostly of South China Sea affinity (e.g., Lu and Hsu 1992; Chang et al. 2003; Zhang et al. 2016; Tian et al. 2019); debates remain for the origin of the ophiolitic rocks in the Lichi Mélange as either Philippine Sea Plate/Luzon forearc (e.g., Juan et al. 1980; Malavieille et al. 2002; Chang et al. 2009; Huang et al. 2018) or South China Sea (e.g., Chung and Sun 1992; Hsieh et al. 2017); the mafic blocks within the Yuli Belt have been inferred from the South China Sea (Yui et al. 2014; Chen et al. 2017b; Beyssac et al. 2008) but lack further constraints. Such ambiguities made tectonic interpretation and reconstruction difficult and fraught with uncertainties, especially for the LichiYuli pair on the opposing sides of the active plate boundary, the Longitudinal Valley (Fig. 1). Protolith origin(s) must be resolved as a prerequisite for comprehensive knowledge on the tectonic processes bringing these two ophiolite-bearing belts of contrasting histories against each other along the plate suture.

One of the best approaches to distinguishing the ophiolitic rocks as originated from the South China Sea or the Luzon forearc region of the Philippine Sea Plate is age-dating of rock formation. The South China Sea was opened since $\sim 37$ to $\sim 15 \mathrm{Ma}$ according to seafloor magnetic anomaly interpretations (Taylor and Hayes 1983; Briais et al. 1993; Yeh et al. 2010), and the oceanic crust southwest of Taiwan yielded ages around $20 \mathrm{Ma}$ (Wang et al. 2012).

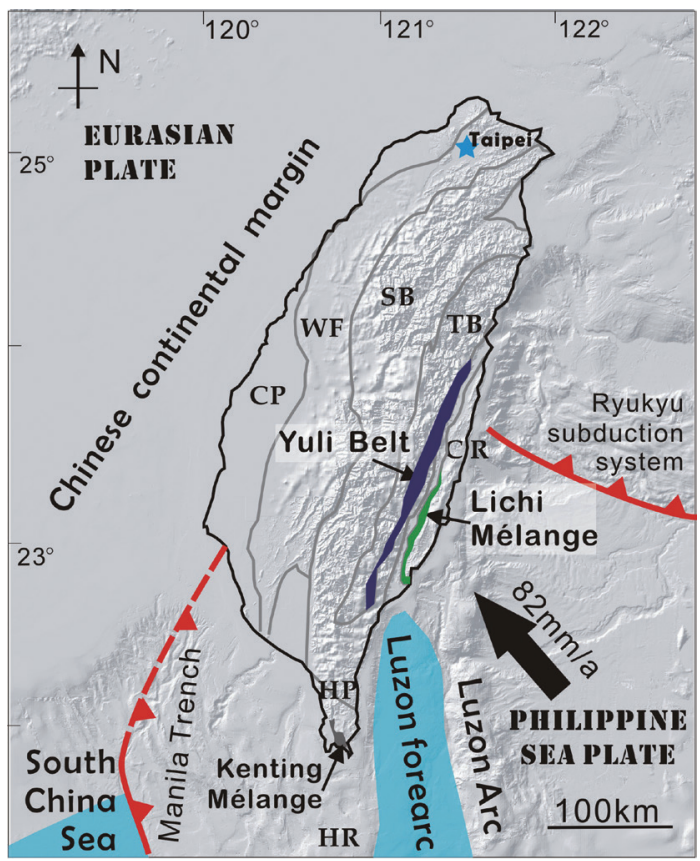

Fig. 1. Tectonic framework of the Taiwan arc-continent collision. The ophiolite-containing geologic units: Yuli Belt, Lichi Mélange, and Kenting Mélange are highlighted. CP: Coastal Plain; WF: Western Foothills; SB: Slate Belt; TB: Tailuko Belt; CR: Coastal Range; HP: Hengchun Peninsula; HR: Hengchun Ridge (submarine accretionary prism). 
The ocean floor immediately east of southeastern Taiwan on the Philippine Sea Plate was interpreted to be either Eocene ( $\sim 50$ to $\sim 40$ Ma: Karig et al. 1975; Sibuet et al. 2002) or Cretaceous ( 130 to $\sim 120$ Ma: Deschamps et al. 2000; Queano et al. 2007). Therefore, the crystallization ages of the igneous protoliths, such as zircon $\mathrm{U}-\mathrm{Pb}$ ages, provide the most unequivocal evidences for clarifying ophiolite origin, especially for the strongly metamorphosed rocks of the Yuli Belt. Further constraints may come from thermochronometers including mineral ${ }^{40} \mathrm{Ar} /{ }^{39} \mathrm{Ar}$ ages for revealing the thermal history important in tectonic reconstructions of the collisional processes.

In this study, age dating of the ophiolitic rocks in the Lichi Mélange and the Yuli Belt by zircon U-Pb laser ablation and ${ }^{40} \mathrm{Ar} /{ }^{39} \mathrm{Ar}$ step-heating techniques were carried out to discriminate the oceanic domains they originated. The results are incorporated into regional tectonic context to build a working hypothesis demonstrating how the South China Sea lithosphere subducted to various depths subsequently entered the ophiolite-bearing units within the orogen, leading to an updated tectonic reconstruction of the Taiwan arccontinent collision.

\section{GEOLOGICAL BACKGROUND AND SAMPLING}

The Taiwan Island is located on the collisional junction between the Eurasia and Philippine Sea plates, where the Luzon Arc indented and accreted to the deformed Chinese continental margin (Suppe 1981; Teng 1990; Lu and Hsu 1992). The collision was achieved in two stages: first the Manila Trench was choked by the arrival of Chinese continental margin after subduction of the South China Sea (Lin et al. 2009); then shortening within the upper Philippines Sea Plate, caused by reduced plate interface slip during continental underthrusting, resulted in forearc closure (Malavieille and Trullenque 2009; Shyu et al. 2011). Because of the oblique configuration of the Chinese continental margin and the Luzon Arc, the collision commenced in the north in Mio-Pliocene time and propagated southward (Suppe 1984), while northeastern Taiwan has entered post-collisional stage (Chen et al. 2014) due to westward propagation of the Ryukyu subduction system with opposite polarity (Teng 1996; Wu et al. 2009). The island is divided in two parts (Fig. 1): east of the Longitudinal Valley (plate suture), the Coastal Range is the accreted Luzon Arc belonging to the Philippine Sea Plate; west of the suture, the Eurasian part of the island is composed of (from west to east) (1) the Coastal Plain as the foreland basin (Lin et al. 2003), (2) the Western Foothills and the Slate Belt as the fold-thrust belt (Chen et al. 2011), (3) the Tailuko Belt as the exhumed continental margin basement (Yui et al. 2012), and (4) the Yuli Belt as an exhumed blueschist-facies subduction complex (Yui et al. 2014; Chen et al. 2017b). The Lichi Mélange is distributed along the western flank of southern Coastal Range, with its matrix composed of sheared forearc sedimentary sequence (Chang et al. 2001; Chen et al. 2017a). The Kenting Mélange crops out in the western side of the fold-thrust belt in the southern tip of the island, with west-vergent thrust contacts to neighboring sedimentary successions and characteristics of subduction zone mega-thrust (Chang et al. 2003).

\subsection{The Yuli Belt}

The Yuli Belt occupies a narrow strip on the eastern flank of the Central Range, the main geomorphic expression of the active arc-continent collision. It is composed of greenschist-facies quartz-mica schist with minor greenschist of Miocene deep-sea sediment protolith (Chen et al. 2017b), and part of it exhibits a tectonic block-in-matrix configuration; the blocks include greenschist, serpentinite and other meta-ophiolitic rocks, some bearing blueschist-facies highpressure (HP) metamorphism such as the epidote amphibolite and glaucophane schist in Juisui area and the omphacite-zoisite metabasite in Wanjung area (Fig. 2; Liou 1981; Yui and Lo 1989; Tsai et al. 2013). The Juisui glaucophane schist, whose protolith was probably a mixture of basaltic tuff and deep-sea sediments (Jahn et al. 1981; Sun et al. 1998 ), was recently dated as $\sim 15$ Ma of igneous crystallization age (Chen et al. 2017b). Also in the Juisui Tamayen tectonic block, epidote amphibolite yielded an age of $\sim 80 \mathrm{Ma}$ using Rb-Sr mineral isochron (Jahn et al. 1981), indicating possible mixture of Cretaceous rocks (Yui et al. 2014). In the Chinshuichi area, HP metamorphism was found in a mélange unit containing both meta-ophiolitic and metasedimentary (garnet-bearing spotted schist) rocks (Keyser et al. 2016). The peak metamorphic condition was estimated to be $\sim 550^{\circ} \mathrm{C}$ (Beyssac et al. 2008) and up to $\sim 13 \mathrm{kbar}$ (Baziotis et al. 2017) for the HP blocks, and a prominent greenschist-facies metamorphic overprint throughout the belt (Lo and Yui 1996; Yui et al. 2014). ${ }^{40} \mathrm{Ar} /{ }^{39} \mathrm{Ar}$ ages of 12 - 9 Ma obtained from foliation-defining phengite grains in glaucophane schist (Lo and Yui 1996) probably pinpoint the end of HP metamorphism/subduction considering blocking temperature of Ar diffusion for phengite (Yui et al. 2014), while 6 - $5 \mathrm{Ma}$ Lu-Hf garnet ages have been interpreted as prograde metamorphism in garnet-amphibolite (Sandmann et al. 2015). ${ }^{40} \mathrm{Ar} /{ }^{39} \mathrm{Ar}$ reset ages of $4 \mathrm{Ma}$ from phlogopite in omphacite-zoisite metabasite (Lo and Yui 1996), together with $\mathrm{Rb}$-Sr age of $5 \mathrm{Ma}$ from Juisui epidote-amphibolite (Jahn et al. 1981) as well as the nephrite formation age of \% Ma (Yui et al. 2014) generally marks the Barroviantype metamorphic overprint associated with later collision processes. Continuous exhumation from the peak pressure state for the blueschist blocks might have persisted till today (Brown et al. 2015).

Constraints of protolith age for the meta-ophiolitic rocks, critical in tracking their origin, were lacking. This key issue is tackled by $\mathrm{U}-\mathrm{Pb}$ dating on zircons extracted from 
a meta-gabbro (sample WL-02), now chiefly composed of albite and amphibole, from the Wanjung tectonic block (Fig. 2) which contains omphacite-bearing rocks (Yui and Lo 1989). For the tectonic blocks in the Juisui area (Fig. 2) where a mid-Miocene age was obtained for the glaucophane schist (Chen et al. 2017b), white mica was extracted from an epidote-amphibolite schist of the Tamayen block (sample EA-02) as well as an albitite (albite no less than $70 \%$ volumetrically with minor white mica, probably a meta-plagiogranite) from the nearby Tsunkuanshan block (sample TKA01) for ${ }^{40} \mathrm{Ar} /{ }^{39} \mathrm{Ar}$ step-heating dating to help bracketing the timing of high-pressure metamorphism.

\subsection{The Lichi Mélange}

The Lichi Mélange flanks the southwestern border of the Coastal Range, which is composed of accreted Luzon Arc volcanic edifices (the Tuluanshan Formation) and deformed allochthonous forearc sedimentary sequences (e.g., Chang et al. 2000; Huang et al. 2006). The matrix of the mélange is chaotic mudstone deposited no later than $\sim 3 \mathrm{Ma}$ as part of the lower forearc sequence (Chi et al. 1981; Huang et al. 2008; Chen et al. 2017a) and is mixed with exotic blocks of varying lithology and size (Page and Suppe 1981). In the intensely sheared portions of the mélange, the matrix mudstone lost original stratification and developed penetrative scaly foliation of mesoscale anastomosing curvy fault slip surfaces (Chang et al. 2000, 2009). The severely sheared mélange is either in fault contact to or conformably grading upward into less- or non-sheared equivalent forearc sequence, indicating that the Lichi Mélange was formed by collisionrelated forearc closure/shortening after $\sim 3.5 \mathrm{Ma}$ (Chang et al. 2001, 2009). The exotic blocks in the Lichi Mélange are grouped into: (1) andesitic volcanics originated from the arc to the east; (2) well-lithified (compared to the younger, poorly consolidated arenite of Luzon forearc basin) sandstones of Miocene abyssal turbidites (Sung 1991) sourced from the accretionary prism on the Manila Trench to the west; and (3) fragmented ophiolitic rocks collectively named as East Taiwan Ophiolite (ETO; Chung and Sun 1992). The ETO blocks are found throughout the Lichi Mélange and consist of ophiolitic lithologies from ocean-floor fossiliferous red clay/chert, pillow or glassy basalt, basaltic dykes, gabbro, plagiogranite, to serpentinized peridotite (Suppe et al. 1981). Petrological and geochemical studies suggest the ETO was formed in a deep-sea slow-spreading ridge (Jahn 1986; Chung and Sun 1992; Hsieh et al. 2017). However, whether the ETO was generated from a ridge on the South China Sea

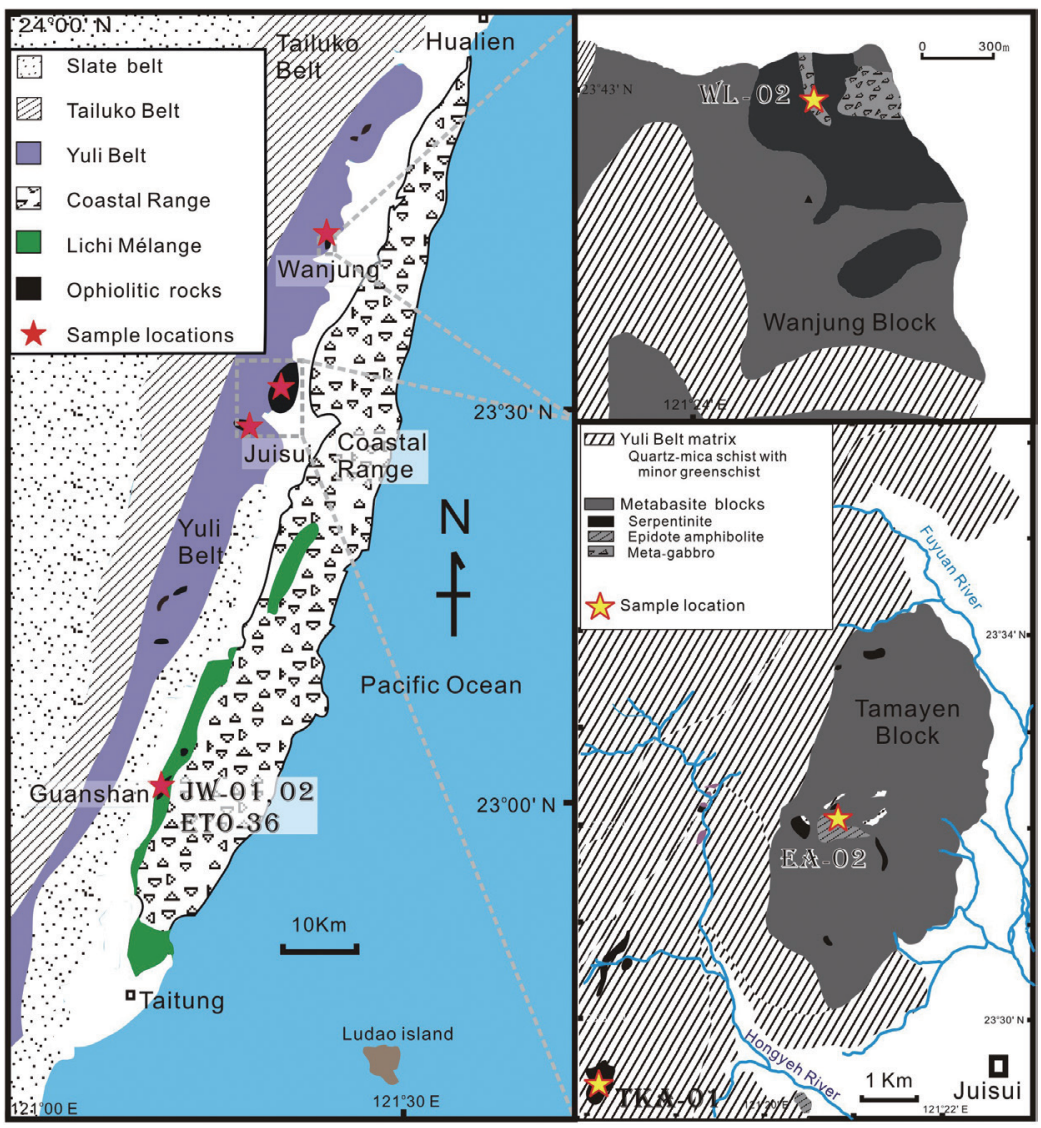

Fig. 2. Regional and detailed geological maps of the Yuli Belt and the Lichi Mélange (modified from Lan 2011; Tsai et al. 2013; Baziotis et al. 2017). Sample localities are marked. 
(e.g., Chung and Sun 1992; Shellnutt and Hsieh 2016; Hsieh et al. 2017) or the Philippine Sea Plate (e.g., Chang et al. 2009; Huang et al. 2018) remained an open question. The recipe is the crystallization age of the ophiolitic rocks since the neighboring South China Sea and the Philippine Sea Plate were formed at different time intervals (Oligo-Miocene, and Eocene or Cretaceous, respectively; Deschamps et al. 2000; Sibuet et al. 2002; Yeh et al. 2010). Existing constraints include biostratigraphic analysis of the ETO red clay, which indicated mid- to lower-Miocene deposition (NN5; Huang et al. 1979) whereas hiatus between basalt eruption and clay deposition might not be totally ruled out; and zircon $\mathrm{U}-\mathrm{Pb}$ ages of gabbroic rocks and plagiogranite around 17 - $14 \mathrm{Ma}$ (Shao 2015; Hsieh et al. 2017; Huang et al. 2018).

To elucidate the ETO formation age, the ophiolitic rocks in the Dianguang locality (near Guanshan Township) of southern Coastal Range (Fig. 2) were sampled for age dating analyses. A contiguous block of ETO ophiolite up to $\sim 1.6 \mathrm{~km}$ in length crops out along the Chiawu creek at the locality in the Guanshan Township, in which the extrusive sequence is found in the western part and the plutonic rocks in the east. Zircon grains were extracted from chert and gabbro samples (samples JW-01 and 02, respectively) and dated by U-Pb laser ablation method. A pillow basalt sample was dated by ${ }^{40} \mathrm{Ar} /{ }^{39} \mathrm{Ar}$ step-heating analysis (sample ETO-36).

\subsection{Sample Description}

\subsubsection{Yuli Belt Samples}

The amphibole-albite rock WL-02 was sampled from an outcrop near Wanjung Cemetery in the northern part of the Wanjung block $(23.71622,121.40759)$, which has been mapped as meta-gabbro or amphibole-albite rock (Liou 1981; Lan and Liou 1984; Lin 1999; Fig. 2). In the field this rock is composed of whitish bands with foliation-parallel $\mathrm{cm}$-long green porphyroblasts, and such metamorphic banding has been folded with ductile deformation (Fig. 3a). Under microscope, the whitish band matrix of the rock is composed of albite and zoisite intergrowth with few paragonite; the green porphyroblasts are amphibole and minor chlorite with few titanite and quartz inclusions (Fig. 3e). The amphiboles are euhedral, and zoned with magnesiohornblende, pargasite or tremolite cores and mostly rimmed by actinolite.

The epidote amphibolite EA-02 was sampled next to glaucophane schist (blueschist) from an abandoned serpentine mine in Tamayen block, Juisui area of the Yuli Belt. Visible euhedral amphibole crystals are embedded in epidote matrix with minor phengite, zoisite, quartz, and garnet (Fig. 3f), a texture similar to the neighboring glaucophane schist and probably corresponding to type I of glaucophanebearing rock of Tsai et al. (2013).

The sample TKA-01 was taken from a serpentinite mine in the Tsunkuanshan block of the Yuli Belt, south of Juisui area. The non-foliated rock is composed of mm-sized white crystals with minor interstitial greenish minerals and occasional large pyrite (Fig. 3b), and constitutes a lithological zonation above the serpentinite. Petrographic analysis reveals that the rock is an albitite containing at least $70 \%$ of large (up to $3 \mathrm{~mm}$ ) euhedral to lathed albite crystals, and white mica without preferred orientation fills the remaining space (Fig. 3g). Albite grains are often twinned, and tiny quartz inclusions form curved trails. Euhedral titanite crystals occur independently or as inclusions, while apatite mostly appears together with white mica. Preliminary inference about the protolith of this albitite might be ophitic plagiogranite or gabbro, with former pyroxene replaced by white mica and accessory minerals whereas plagioclace by albite during sodic metasomatism in high-P shear zones, or altered jadeitite during retrograde reactions (e.g., Harlow 1994; Tsujimori and Harlow 2012).

\subsubsection{Lichi ETO Samples}

All of the three samples (JW-01, 02, ETO-36) were sampled from the ophiolite sequence exposed along the Chiawu Creek in Dianguang, Guanshan, within the Lichi Mélange. JW-01 was sampled from a $\sim 3$ m-wide chert formation within lower part of basalt sequence and close to dolerite (Fig. 3c), and is composed of fine-grained quartz with minor feldspar, and contains minute veinlets filled with prehnite (Fig. 3h). ETO-36 was taken from a nearby fresh pillow basalt. JW-02 is a coarse-grained gabbro taken from a fresh outcrop in the lower part of the ophiolite sequence (Fig. 3d) and composed of large granoblastic clinopyroxene and plagioclase crystals without apparent traces of metamorphism or alteration (Fig. 3i).

\section{ANALYTICAL METHODS}

\subsection{Zircon U-Pb Laser Ablation Analysis}

Zircon grains were mechanically separated from the samples using conventional heavy-liquid and magnetic separation techniques. Zircon grains with crystal lengths $>100 \mu \mathrm{m}$ were linearly mounted with epoxy resin and then polished. Cathodoluminescence (CL) images were taken for examining the internal structures of individual zircon grains. Laser ablation inductively coupled plasma mass spectrometer (LA-ICP-MS) U-Pb dating was carried out using an Agilent 7500s quadrupole ICP-MS coupled with a New Wave UP-213 laser ablation system housed in the Department of Geosciences, National Taiwan University. The ablation beam diameter was about $30 \mu \mathrm{m}$. Operating conditions and analytical procedures followed Chiu et al. (2009). The laser ablation spot was placed in the center of each analyzed zircon grains. The results are presented in Fig. 4 and Table 1. 


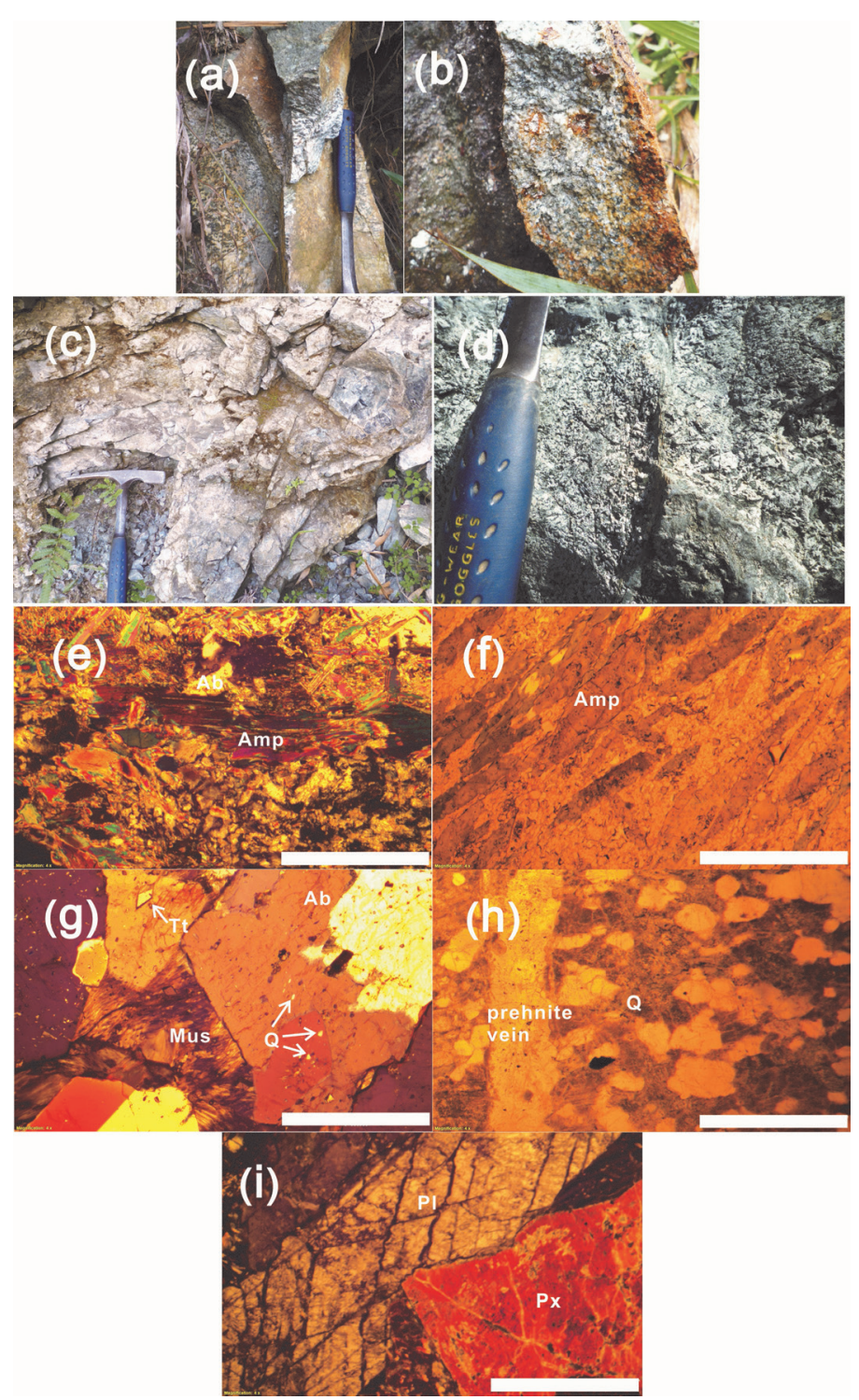

Fig. 3. Field occurrence and petrography of analyzed samples. (a) Field photo of WL-02, meta-gabbro from Wanjung block in Yuli Belt, exhibiting deformed greenish mineral banding; (b) field photo of TKA-1, coarse-grained albitite from Tsunkuanshan block in Yuli Belt; (c) field photo of JW01, chert formation within ETO basalt in Lichi Mélange; (d) field photo of JW-02, fresh ETO gabbro in Lichi Mélange; (e) photomicrograph of WL02 (crossed polars) showing amphibole crystals in matrix of anhedral albite and minor minerals; (f) photomicrograph of EA-02, epidote amphibolite from Tamayen block in Yuli Belt, showing amphibole crystals in matrix of fine-grained epidote and minor minerals; (g) photomicrograph of TKA01 (crossed polars), exhibiting large euhudral albite crystals with white mica filling in interstitial spaces, and occurrences of quartz inclusions and titanite crystals; (h) photomicrograph of JW-01, a prehnite vein crosscutting chert formation; and (i) photomicrograph of JW-02 (crossed polars), exhibiting plutonic texture of coarse-grained clinopyroxene and plagioclase. Light grey bar in E-I indicate 1 mm length. Mineral abbreviations: Ab: albite, Amp: amphibole, Mus: muscovite, Pl: plagioclase, Px: pyroxene, Q: quartz, Tt: titanite. 
(a) WL-02 Meta-gabbro

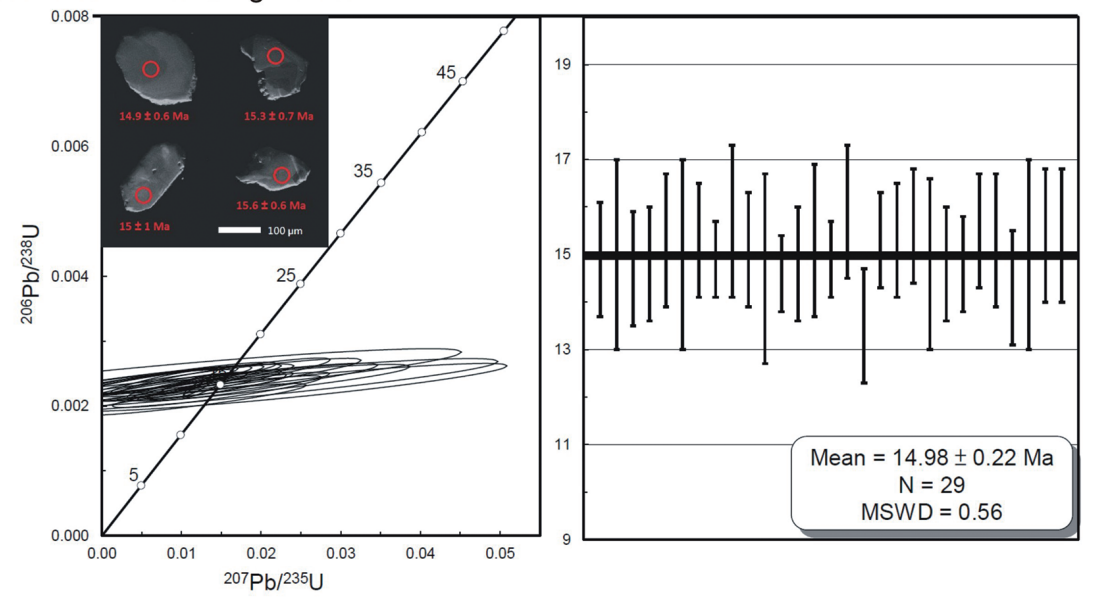

(b) JW- 01 Chert

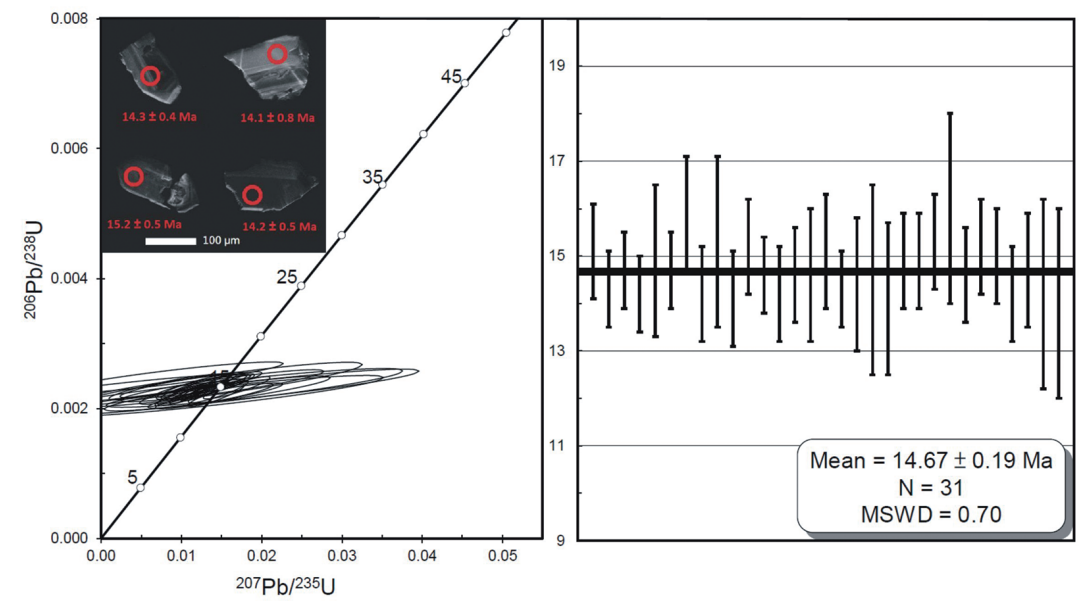

(c) JW-02 Gabbro

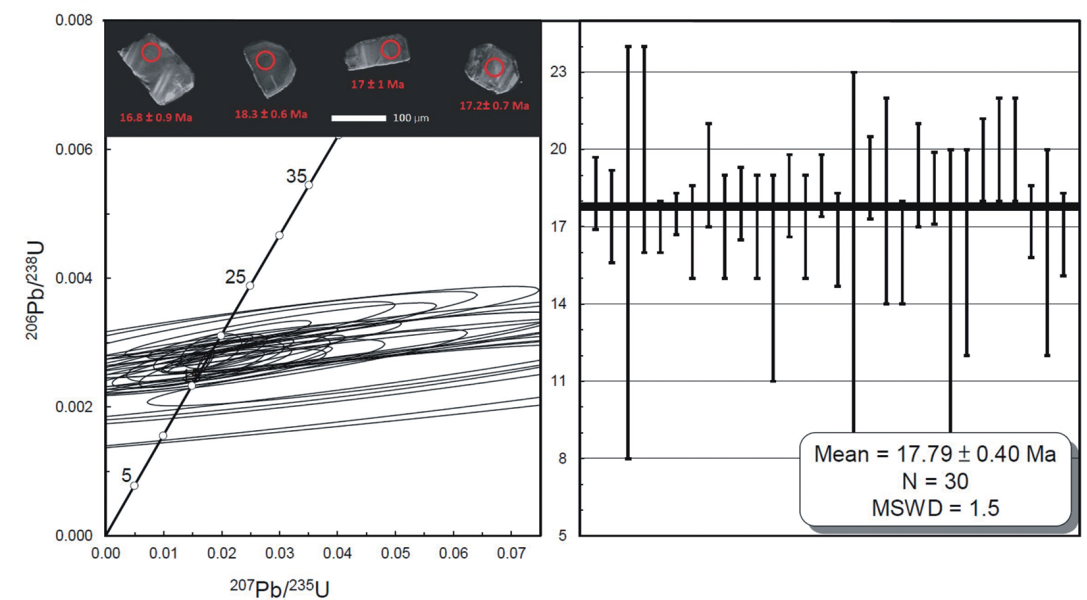

Fig. 4. Zircon dating results for samples, (a) WL-02 meta-gabbro, (b) JW-01 chert, and (c) JW-02 gabbro. 


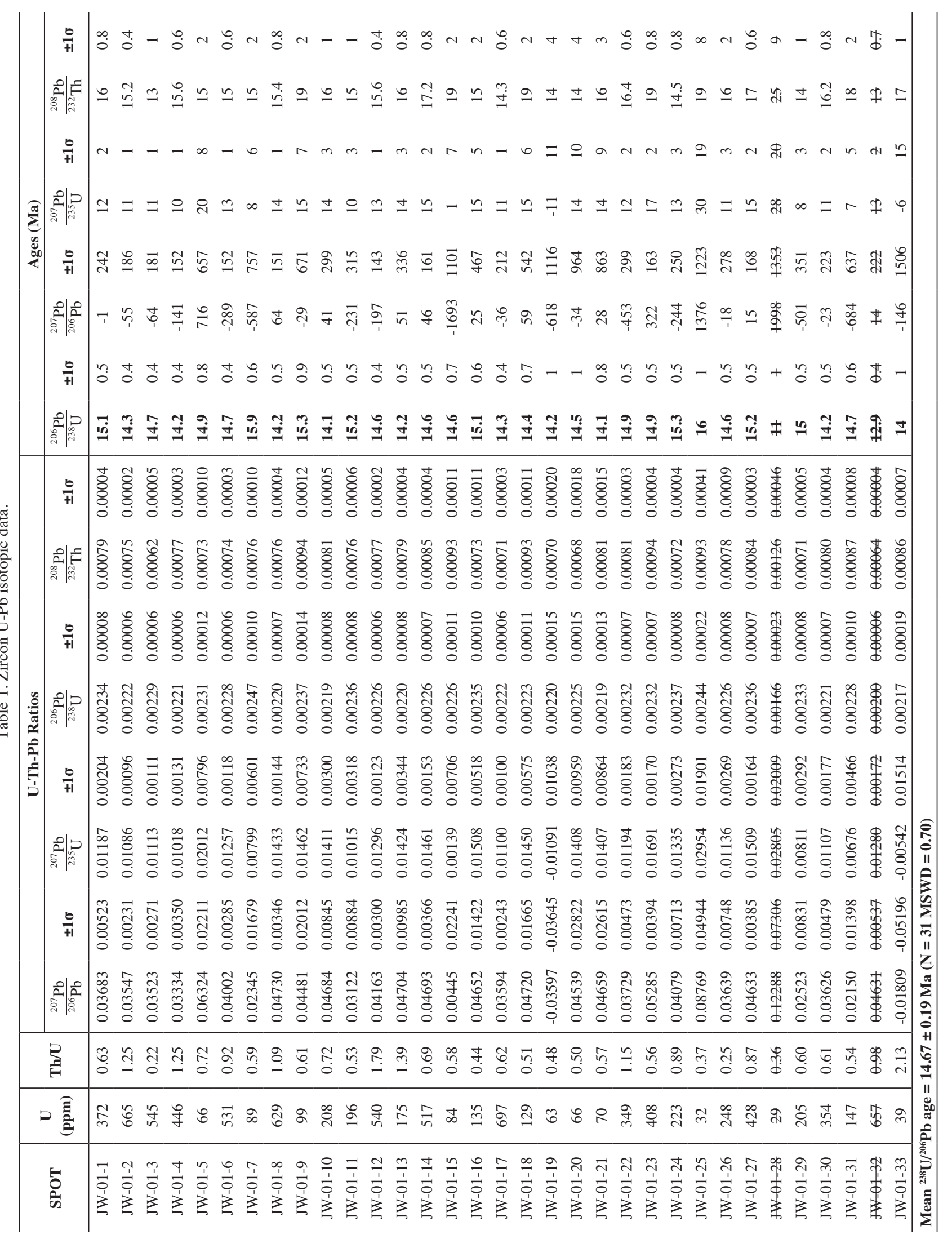




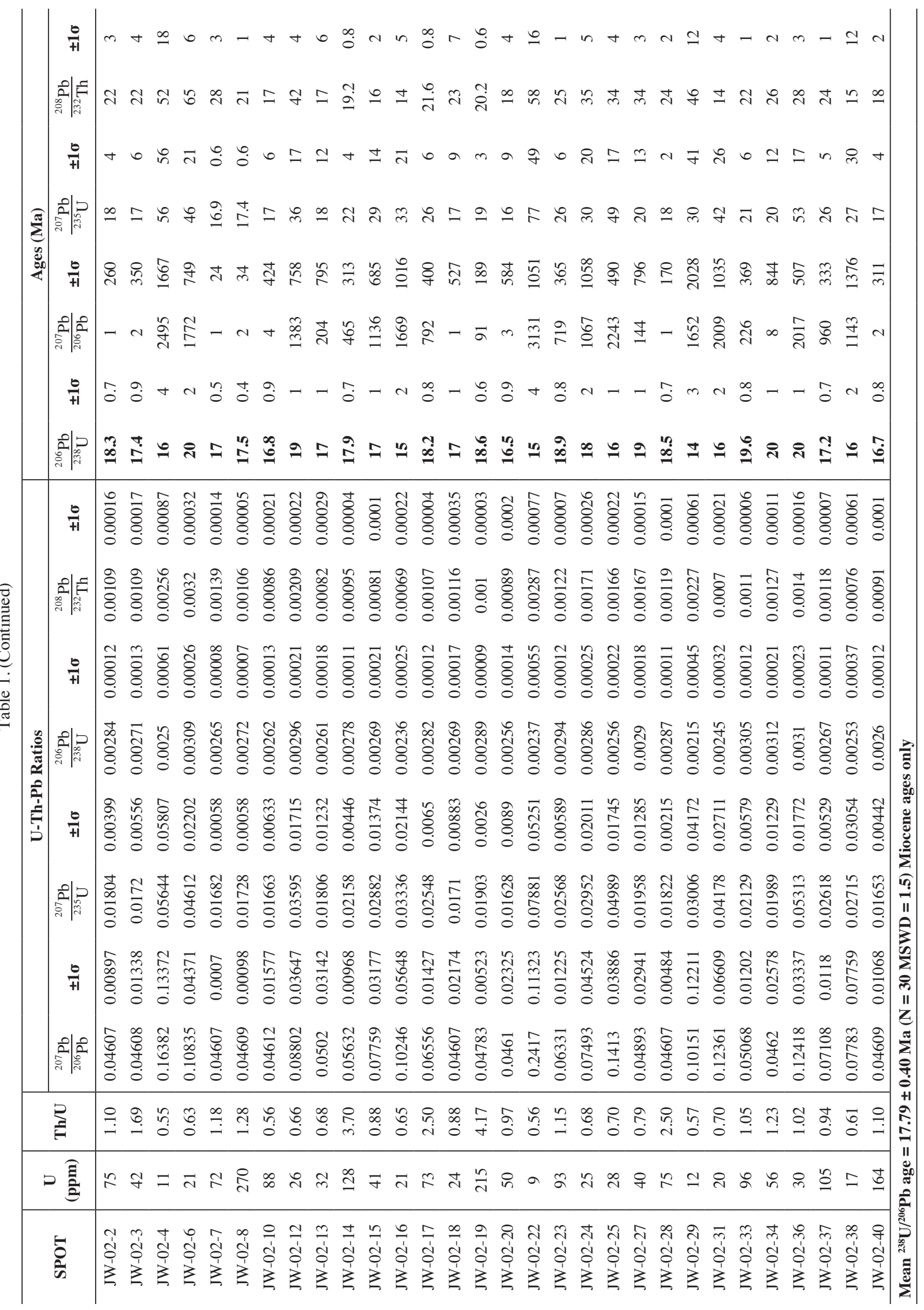




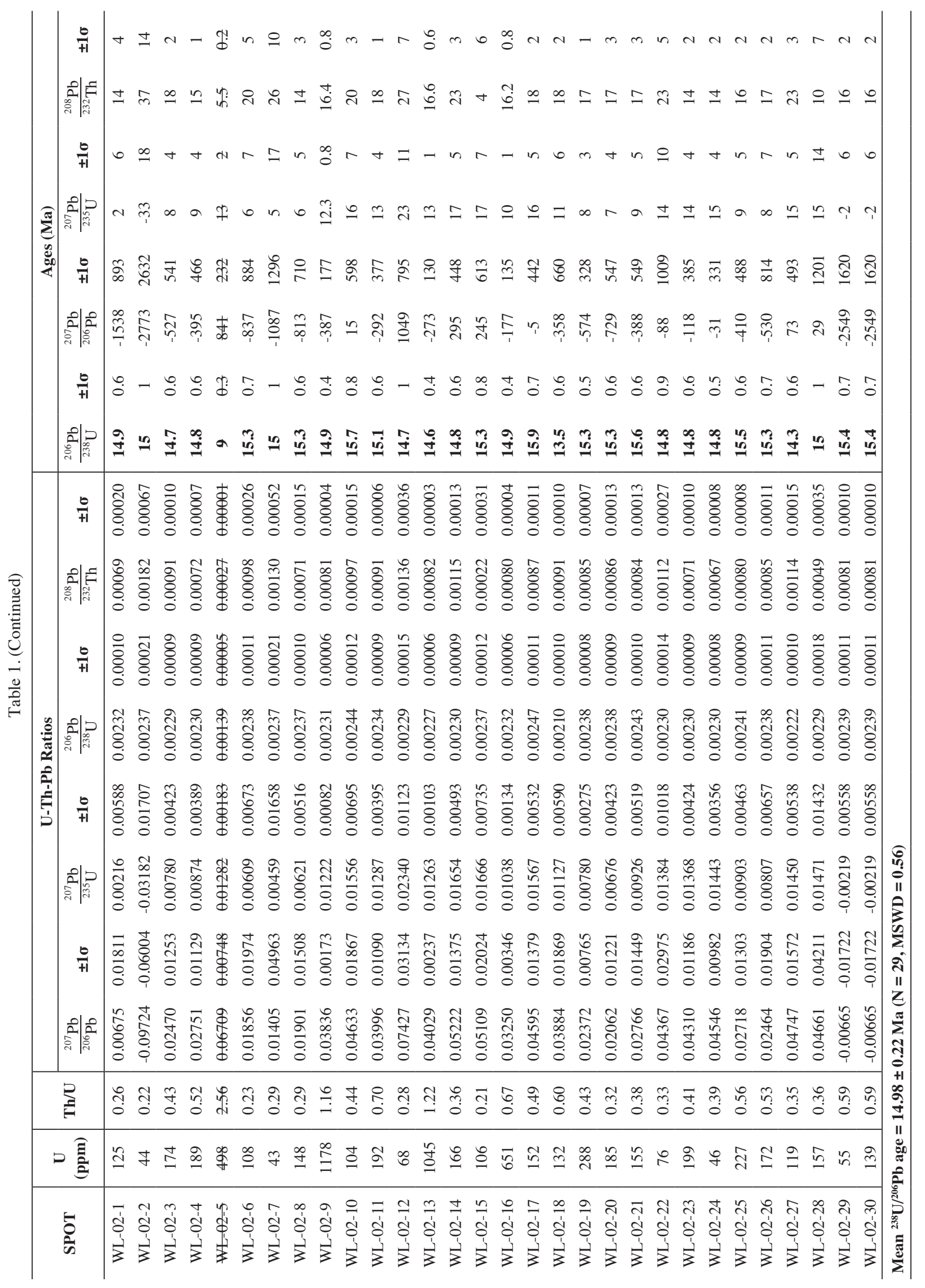




\section{$3.2{ }^{40} \mathrm{Ar} /{ }^{39} \mathrm{Ar}$ Step-Heating Analysis}

White mica grains of the Yuli samples were mechanically separated from the samples using conventional heavyliquid and magnetic separation techniques, and the ETO basalt sample was crushed and disintegrated. After sieving, grain sizes between 140 - $250 \mu \mathrm{m}$ were ultrasonically cleaned with acetone and deionized water then dried. The washed grains were handpicked to remove visible contamination to obtain pure separates. Weighted sample separates were wrapped in aluminum packets and packed with LP-6 Biotite standard for irradiation. After irradiation, the LP-6 biotite standard and samples were measured with step-heating technique, incrementally heated from 500 to $1500^{\circ} \mathrm{C}$ using a double-vacuum resistance furnace, with a $30-\mathrm{min}$ step schedule. Purified gas analyzed by a VG1200 mass spectrometer at the Argon geochronology laboratory, National Taiwan University.

${ }^{40} \mathrm{Ar} /{ }^{39} \mathrm{Ar}$ date was calculated from the argon composition released from the LP-6 biotite monitor (Odin 1982) with a calibrated ${ }^{40} \mathrm{Ar} /{ }^{39} \mathrm{Ar}$ age of $128.48 \pm 0.64$ Ma based on Fish Canyon Sanidine (28.294 $\pm 0.036 \mathrm{Ma}$; Renne et al. 2010,2011 ) with $\mathrm{R}$ value of $4.669 \pm 0.023$. Details of the analytical procedure are given in Lo et al. (2002). Plateau ages are calculated on adjacent steps with similar ages, which together comprise more than $50 \%$ of ${ }^{39} \mathrm{Ar}_{\mathrm{K}}$ released. The results are presented in Fig. 5 and Table 2.

\section{RESULTS}

\subsection{Zircon U-Pb Dating Results}

Zircon grains extracted from sample WL-02 (a metagabbro from Wanjung) are mostly euhedral with lengths ranging from 100 to $350 \mu \mathrm{m}$. No perceptible rims of metamorphic zircon growth were found in the CL images and substantiated by the obtained $\mathrm{Th} / \mathrm{U}$ ratios $(0.22-1.28$; metamorphic zircon growths usually have ratios $<0.1$, Rubatto 2002). The analyzed zircon grains yielded concordant and consistent ages with a weighted mean of $14.98 \pm 0.22 \mathrm{Ma}$, and no inherited zircon was detected (Fig. 4a). The result indicates that the gabbro protolith of sample WL-02 was crystallized at $\sim 15 \mathrm{Ma}$.

Of the ETO samples, sample JW-01 yielded 31 zircon grains, which are magmatic in origin and $100-200 \mu \mathrm{m}$ in length. Their ages are tightly clustered around a weighted mean of $14.67 \pm 0.19 \mathrm{Ma}$ with $\mathrm{Th} / \mathrm{U}$ ratios between 0.25 and 1.79 (Fig. 4b); since no inherited zircon was found, the chert may be interpreted as deposited concurrently with $\sim 15$ Ma eruption which was probably tuffaceous. Zircons from sample JW-02 are smaller and some of the population are pre-Miocene and thus inherited; 30 zircon grains produced concordant ages with a weighted mean of $17.79 \pm 0.4 \mathrm{Ma}$ and $\mathrm{Th} / \mathrm{U}$ ratios of $0.56-4.17$ (Fig. 4c), representing the crystallization age of the gabbro sample.

\section{$4.2{ }^{40} \mathrm{Ar} /{ }^{39} \mathrm{Ar}$ Step-Heating Results}

White mica from both epidote-amphibolite schist of the Tamayen block and albitite from the Tsunkuanshan block in the Yuli Belt display fairly flat age spectra over more than $93 \%$ of ${ }^{39} \mathrm{Ar}_{\mathrm{K}}$ released with similar plateau ages (Figs. $4 \mathrm{a}$ and b). Both plateau ages of EA-02 (8.97 \pm 0.27 Ma) and TKA-01 (9.19 $\pm 0.27 \mathrm{Ma})$ are consistent with their respective intercept ages $(9.15 \pm 0.69$ and $8.96 \pm 0.56$ $\mathrm{Ma}$, respectively). Isotope correlation plots indicate initial ${ }^{40} \mathrm{Ar} /{ }^{36} \mathrm{Ar}$ values $(292.9 \pm 9.0$ for EA-02 and $298.3 \pm 6.0$ for TKA-01) close to the atmospheric composition (298.65; Lee et al. 2006a), demonstrating absence of apparent excess argon (Figs. $4 \mathrm{a}$ and $\mathrm{b}$ ). These $\sim 9 \mathrm{Ma}{ }^{40} \mathrm{Ar} /{ }^{\beta 9} \mathrm{Ar}$ ages are significantly younger than the $\sim 15 \mathrm{Ma}$ zircon $\mathrm{U}-\mathrm{Pb}$ ages from meta-gabbro (sample WL-02, section 4.1) (Fig. 4a) or glaucophane schist (Chen et al. 2017b) and could be related to the blueschist-facies metamorphism, since the later greenschist overprint was generally constrained to be $\sim 3-4 \mathrm{Ma}$ (Yui et al. 2014). However, this inference is in conflict with the published garnet prograde growth age from Tamayen garnet amphibolite (Sandmann et al. 2015), and needs further deliberation as in the following Discussion part.

The basalt sample from the Lichi Mélange, ETO-36, yielded whole-rock flat age spectrum with plateau age of $13.93 \pm 0.55 \mathrm{Ma}$ over $94.5 \%$ of the total ${ }^{39} \mathrm{Ar}_{\mathrm{K}}$ released (Fig. 5c). Isotope correlation plot results in an intercept age of $14.79 \pm 1.21 \mathrm{Ma}$ and an ${ }^{40} \mathrm{Ar} /{ }^{36} \mathrm{Ar}$ initial value of 263.19 $\pm 42.7(\mathrm{MSWD}=0.14)$. The intercept age is consistent with the zircon ages of sample JW-01, indicating the magmatic zircon grains within the chert deposit (JW-01) were cogenetic with the neighboring basalts.

\section{DISCUSSIONS}

\subsection{Origins of the Ophiolitic Rocks in the Yuli Belt and the Lichi Mélange}

During the development of the Taiwan arc-continent collision, the South China Sea and the Luzon forearc lithosphere have been consumed leading to head-on buttressing between the deformed Luzon Arc and the exhumed metamorphosed Chinese continental margin along the Longitudinal Valley suture. How the Yuli and the Lichi ophiolite-bearing belts paired across the suture correlate to the two oceanic realms, however, remained speculative (e.g., Malavieille et al. 2002; Beyssac et al. 2008; Chang et al. 2009; Chen et al. 2017b). The most definitive constraints may come from the crystallization and eruption ages of the oceanic crustal rocks as either the Oligo-Miocene South China Sea or the Eocene to Cretaceous Luzon forearc. For the ophiolitic rocks in the Yuli Belt, the zircon crystallization ages of the meta-gabbro sample WL-02 from the Wanjung area as well as those reported from blueschist samples of the Juisui area (Chen et al. 2017b) suggest the 
(a) EA-02 Muscovite/white mica from epidote amphibolite
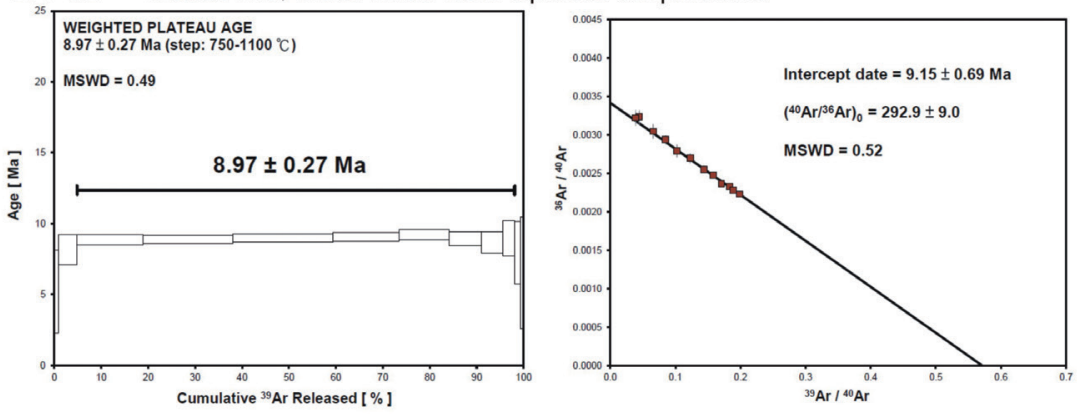

(b) TKA-01 Muscovite/white mica from albitite
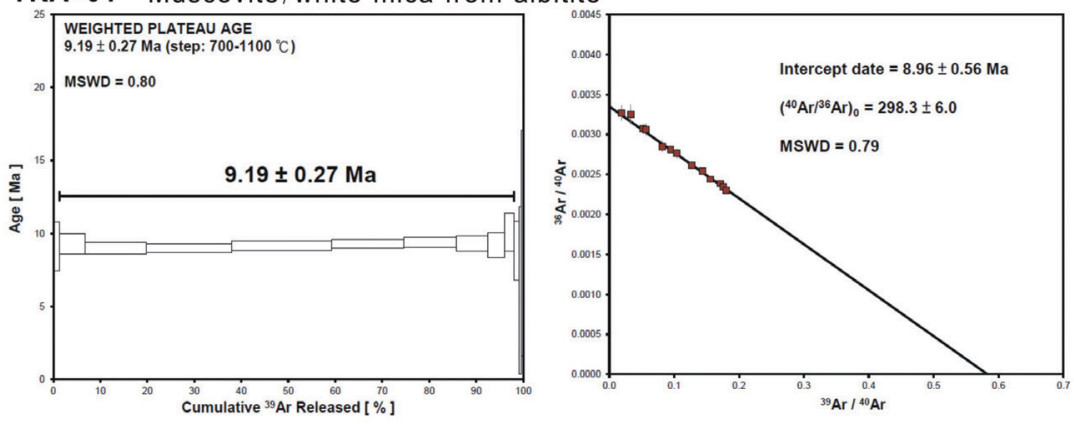

(c) ETO-36 Basalt whole rock
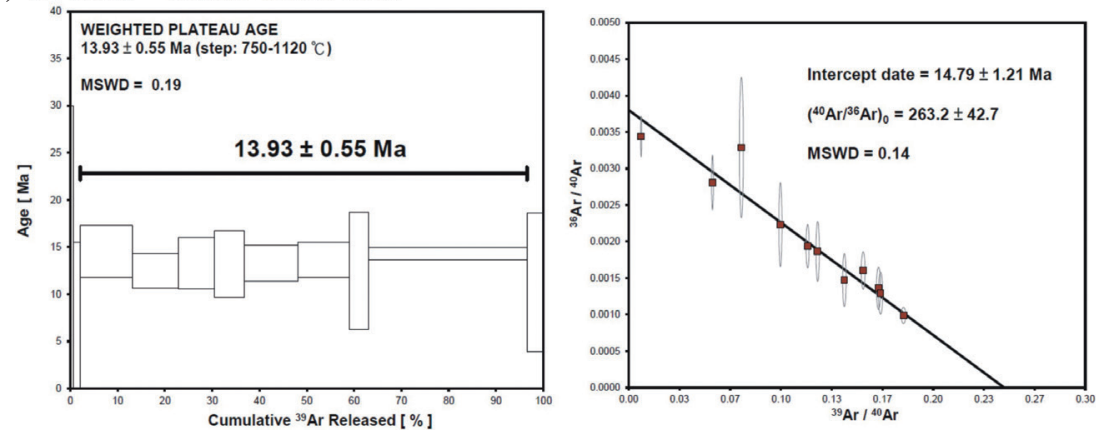

Fig. $5 .{ }^{40} \mathrm{Ar} /{ }^{39} \mathrm{Ar}$ age spectra and isotope correlation diagrams for samples (a) EA-02 white mica, (b) TKA-01 white mica, and (c) ETO-36 basalt whole rock.

Table. 2. Analytical results of ${ }^{40} \mathrm{Ar} /{ }^{39} \mathrm{Ar}$ dating.

\begin{tabular}{ccccccccc}
\hline \multicolumn{7}{c}{ Sample ID: EA-02 Mus } \\
\hline Step* & cum. ${ }^{39} \mathbf{A r}$ \\
K & Atmos. (\%) & ${ }^{36} \mathbf{A r}{ }^{39} \mathbf{A r}$ & ${ }^{37} \mathbf{A r} /{ }^{39} \mathbf{A r}$ & ${ }^{38} \mathbf{A r} /{ }^{39} \mathbf{A r}$ & ${ }^{40} \mathbf{A r} /{ }^{39} \mathbf{A r}$ & ${ }^{40} \mathbf{A r}{ }^{36} \mathbf{A r}$ & Age (Ma) \pm 1SD \\
\hline $600^{\circ} \mathrm{C}$ & 0.009 & $91.35 \%$ & $.7235 \mathrm{E}-01$ & $.3135 \mathrm{E}-01$ & $.2563 \mathrm{E}-01$ & $.2240 \mathrm{E}+02$ & $.3097 \mathrm{E}+03$ & $5.22 \pm 2.94$ \\
$700^{\circ} \mathrm{C}$ & 0.049 & $76.38 \%$ & $.3448 \mathrm{E}-01$ & $.8957 \mathrm{E}-02$ & $.1855 \mathrm{E}-01$ & $.1178 \mathrm{E}+02$ & $.3416 \mathrm{E}+03$ & $8.16 \pm 1.05$ \\
$750^{\circ} \mathrm{C}$ & 0.190 & $57.51 \%$ & $.1566 \mathrm{E}-01$ & $.3654 \mathrm{E}-02$ & $.1504 \mathrm{E}-01$ & $.6350 \mathrm{E}+01$ & $.4055 \mathrm{E}+03$ & $8.85 \pm 0.38$ \\
$800^{\circ} \mathrm{C}$ & 0.381 & $52.27 \%$ & $.1269 \mathrm{E}-01$ & $.4411 \mathrm{E}-02$ & $.1448 \mathrm{E}-01$ & $.5477 \mathrm{E}+01$ & $.4315 \mathrm{E}+03$ & $8.87 \pm 0.29$ \\
$850^{\circ} \mathrm{C}$ & 0.593 & $48.91 \%$ & $.1121 \mathrm{E}-01$ & $.1157 \mathrm{E}-01$ & $.1421 \mathrm{E}-01$ & $.5058 \mathrm{E}+01$ & $.4510 \mathrm{E}+03$ & $8.96 \pm 0.28$ \\
$900^{\circ} \mathrm{C}$ & 0.735 & $50.51 \%$ & $.1208 \mathrm{E}-01$ & $.1717 \mathrm{E}-01$ & $.1437 \mathrm{E}-01$ & $.5329 \mathrm{E}+01$ & $.4413 \mathrm{E}+03$ & $9.05 \pm 0.31$ \\
$950^{\circ} \mathrm{C}$ & 0.841 & $53.46 \%$ & $.1383 \mathrm{E}-01$ & $.2311 \mathrm{E}-01$ & $.1469 \mathrm{E}-01$ & $.5877 \mathrm{E}+01$ & $.4250 \mathrm{E}+03$ & $9.21 \pm 0.38$ \\
$1000^{\circ} \mathrm{C}$ & 0.911 & $60.38 \%$ & $.1778 \mathrm{E}-01$ & $.2538 \mathrm{E}-01$ & $.1543 \mathrm{E}-01$ & $.6990 \mathrm{E}+01$ & $.3931 \mathrm{E}+03$ & $8.93 \pm 0.50$ \\
$1050^{\circ} \mathrm{C}$ & 0.956 & $65.97 \%$ & $.2198 \mathrm{E}-01$ & $.2954 \mathrm{E}-01$ & $.1622 \mathrm{E}-01$ & $.8181 \mathrm{E}+01$ & $.3722 \mathrm{E}+03$ & $8.67 \pm 0.77$ \\
$1100^{\circ} \mathrm{C}$ & 0.981 & $69.98 \%$ & $.2725 \mathrm{E}-01$ & $.3677 \mathrm{E}-01$ & $.1720 \mathrm{E}-01$ & $.9790 \mathrm{E}+01$ & $.3593 \mathrm{E}+03$ & $8.95 \pm 1.24$ \\
$1200^{\circ} \mathrm{C}$ & 0.993 & $81.65 \%$ & $.4633 \mathrm{E}-01$ & $.4150 \mathrm{E}-01$ & $.2077 \mathrm{E}-01$ & $.1524 \mathrm{E}+02$ & $.3289 \mathrm{E}+03$ & $7.96 \pm 2.20$ \\
$1350^{\circ} \mathrm{C}$ & 1.000 & $90.65 \%$ & $.8279 \mathrm{E}-01$ & $.4420 \mathrm{E}-01$ & $.2758 \mathrm{E}-01$ & $.2574 \mathrm{E}+02$ & $.3109 \mathrm{E}+03$ & $6.52 \pm 3.96$ \\
\hline
\end{tabular}

Note: $J$-value $=0.00289630 \pm 0.00003736 ;$ Integrated date $=8.86 \pm 0.31 \mathrm{Ma} ;$ Plateau date $=8.97 \pm 0.27 \mathrm{Ma}$ (step: 750 $\left.1100^{\circ} \mathrm{C}\right) ; M S W D=0.49$ 
original oceanic lithosphere was constructed around $15 \mathrm{Ma}$ (Fig. 4a), indicating that they were derived from the South China Sea lithosphere. The whole-rock ${ }^{40} \mathrm{Ar} /{ }^{39} \mathrm{Ar}$ age of the pillow basalt from the Lichi Mélange (sample ETO-36) (Fig. 5c) indicates the sea-floor eruption took place around 14 - $15 \mathrm{Ma}$, and the eruption might have provided the zircons with ages tightly clustered $\sim 15 \mathrm{Ma}$ into the overlying and intercalated chert deposit (sample JW-01) (Fig. 4b). Therefore, the ophiolitic rocks in the Lichi Mélange might have been also originated from the South China Sea lithosphere considering the age of mid-ocean ridge basalt (Hsieh et al. 2017) eruption. Prolonged magmatic activity in the mush zone in a slow-spreading ridge environment (Chung and Sun 1992; Shellnutt and Hsieh 2016) might be responsible for the slightly older gabbro crystallization ages from sample JW-02, and not consistent with upper-plate suprasubduction processes (Huang et al. 2018). So far no Luzon forearc basement rocks have been documented via geochronological or petrological means within the Lichi Mélange, indicating that although the Lichi Mélange was formed during forearc basin closure through basement underthrusting/ subduction, the basement rocks (except arc volcanics) were not mixed with overlying sediments. Hence the inferences of South China Sea affinity of the Yuli and Lichi ophiolitic rocks (e.g., Yui et al. 2014; Shao 2015; Chen et al. 2017b; Hsieh et al. 2017), are substantiated by our results that ophiolitic blocks from both belts across the Longitudinal Valley suture are dismembered fragments from the South China Sea lithosphere.

\subsection{Contrasting Thermal-Metamorphic History of Ophiolitic Rocks Across the Longitudinal Valley Suture}

Despite common origin, the Yuli meta-ophiolitic rocks have complex rock history involving HP blueschist metamorphism (Tsai et al. 2013) and later greenschist Barrovian overprint (Yui et al. 2014), in contrast to those in the Lichi Mélange with at most hydrothermal or seafloor metamorphism (Liou and Ernst 1979). Such difference is also demonstrated in the dating results: a considerable time span of $\sim 5$ up to $\sim 11$ million years exists for the Yuli meta-ophiolitic rocks between the zircon crystallization age ( $\sim 15 \mathrm{Ma}$ of the meta-gabbroic rocks, as well as the glaucophane schist reported in Chen et al. 2017b) and their ${ }^{40} \mathrm{Ar} /{ }^{39} \mathrm{Ar}$ ages ( $~ 9 \mathrm{Ma}$ from white mica in meta-gabbroic rocks, 10 - $11 \mathrm{Ma}$ from white mica in glaucophane schist, and $\sim 4 \mathrm{Ma}$ from phlogopite in omphacite-bearing rock in Wanjung in Lo and Yui 1996); while no apparent time lag is found for the ETO in the Lichi Mélange (14 - 15 Ma for both zircons in chert and pillow basalt whole-rock ${ }^{40} \mathrm{Ar} /{ }^{39} \mathrm{Ar}$ ages, as well as zircons from gabbro in Hsieh et al. 2017). The isochronous zircon and ${ }^{40} \mathrm{Ar} /{ }^{39} \mathrm{Ar}$ ages from ETO rocks indicate lack of signifi- cant post-crystallization heating, in line with geologic characteristics of the ETO and the Lichi Mélange as a whole.

For the ophiolitic rocks in the Yuli Belt, the younger white mica ${ }^{40} \mathrm{Ar} /{ }^{39} \mathrm{Ar}$ ages may result from thermal resetting, as the peak condition of the blueschist metamorphism reached $\sim 550^{\circ} \mathrm{C}$ (Beyssac et al. 2008; Keyser et al. 2016; Baziotis et al. 2017) which is higher than the resetting temperature for muscovite $\left(\sim 490^{\circ} \mathrm{C}\right.$; Harrison et al. 2009$)$; therefore the $\sim 9$ - 11 Ma white mica ages represent early retrograde exhumation from peak HP state. Such thermal evolution for Yuli HP rocks is, however, not compatible with blueschist garnet prograde growth ages of $\sim 5-6 \mathrm{Ma}$ (Sandmann et al. 2015). In many eclogite and HP terranes along continental suture zones, excess argon is identified and causes anomalously old apparent ages (e.g., Ruffet et al. 1997); the $9-11 \mathrm{Ma}$ white mica ${ }^{40} \mathrm{Ar} /{ }^{39} \mathrm{Ar}$ ages are hence suspect of contamination from excess argon that makes them older than the garnet prograde growth ages and rendered not relevant. For HP oceanic subduction without polyphase metamorphism, as the situation of Yuli ophiolitic rocks, excess argon is considered negligible (Itaya and Tsujimori 2015); such circumstance corresponds to the atmospheric initial ${ }^{40} \mathrm{Ar} /{ }^{36} \mathrm{Ar}$ value from isotope correlation plots of EA-02 and TKA-01 (Fig. 5) which show no sign of apparent excess argon. When concerning the possible protolith compositions, white mica as a high-K content phase does not correspond to the original bulk compositions of neither EA-02 (basalt/gabbro) nor TKA-01 (plagiogranite/ gabbro); it might originate from seafloor alteration (Putlitz et al. 2005) or by encapsulating fine-grained Yuli meta-sediment matrix through fluid-rock interaction (e.g., Halama et al. 2014; Chen et al. 2016). Therefore, the $\sim 9$ - 11 Ma white mica ${ }^{40} \mathrm{Ar} /{ }^{39} \mathrm{Ar}$ ages of the meta-ophiolitic rocks in the Juisui area might correlate to growth during foliation formation following peak HP metamorphism (cf. Putlitz et al. 2005) and modified by deformation-assisted resetting (cf. Itaya and Tsujimori 2015). To summarize, since no significant excess argon is present, the white mica ${ }^{40} \mathrm{Ar} /{ }^{39} \mathrm{Ar}$ ages indicate that the blueschist meta-ophiolitic blocks reached HP condition and started to exhume at around $9 \mathrm{Ma}$; otherwise the South China Sea oceanic lithosphere was still subducting when continental underthrust/subduction commenced ( 8 - 6.5 Ma for central Taiwan; Lin et al. 2003; Chen et al. 2018) as inferred from the 6 - 5 Ma garnet prograde growth ages (Sandmann et al. 2015). Further investigations are needed to resolve the nature of the $\sim 9$ - $11 \mathrm{Ma}$ white mica ${ }^{40} \mathrm{Ar} /{ }^{39} \mathrm{Ar}$ ages from Yuli meta-ophiolitic rocks. The $\sim 4 \mathrm{Ma}$ phlogopite ${ }^{40} \mathrm{Ar} /{ }^{39} \mathrm{Ar}$ age from omphacite-bearing rocks in the Wanjung area (Lo and Yui 1996) was probably related to the later regional greenschist-facies metamorphic overprint at mid-crustal environment during the arc-continent collision demonstrated in metamorphic zircon overgrowths (Yui et al. 2014). 


\subsection{Working Tectonic Hypothesis for Ophiolite Emplacement}

Emplacement of ophiolitic rocks into the various parts of the Taiwan mountain belt bears key knowledge on the preceding subduction and ongoing arc-continent collision, and their identification as dismembered South China Sea lithosphere through age dating places critical constraints on orogenic evolution. The emplacement mechanism of the South China Sea fragments for each of the three ophiolitecontaining geologic units, however, varies according to their tectonic characteristics; together they illustrate the fate of different parts of the South China Sea lithosphere within the orogen.

The incorporation of the South China Sea ophiolitic materials in the Kenting Mélange occurred during plate boundary shearing that brought footwall rock into the mega-thrust fault zone of the Manila subduction zone (Lu and Hsu 1992; Zhang et al. 2016; Tian et al. 2019), since the Kenting Mélange is a relict subduction fault zone uplifted within the accretionary prism as the Hengchun Ridge/Peninsula (Chang et al. 2009). Thus ophiolitic materials were fed into the matrix of the Kenting tectonic mélange from the onset of South China Sea subduction, which should be prior than the earliest known volcanism in the Luzon Arc of the Taiwan region ( 15 Ma; Yang et al. 1995; Lai et al. 2017; or $\sim 18 \mathrm{Ma}$; Huang et al. 2018), until the trench jump (PlioPleistocene; Chang et al. 2009).

The occurrence of South China Sea fragments as the Eastern Taiwan Ophiolite in the Lichi Mélange is intimately related to the Hengchun Ridge accretionary prism and the Kenting subduction mélange (Suppe et al. 1981; Malavieille et al. 2016). During the growth of the Hengchun Ridge, the sediment-ophiolite mixture of the subduction mélange was underthrust along Manila subduction channel beneath the wedge, meanwhile strong backthrusting in the retrowedge drove rock uplift and mass wasting as topography steepened (Malavieille et al. 2016). Therefore, some pieces of the South China Sea lithosphere caught in the subduction channel were first basal-accreted into the deeper portion of the accretionary prism (Malavieille and Trullenque 2009; McIntosh et al. 2013), and then exhumed at the eastern side of the Hengchun Ridge along backthrusts and shed into the neighboring Luzon forearc basin (Page and Suppe 1981; Malavieille et al.2016). Such olistostromal process is observed offshore SE Taiwan where chaotic slump deposits sourced from Hengchun Ridge/Peninsula to the west were identified in the Huatung Ridge (Chi et al. 2014) as proto-Lichi Mélange (Huang et al. 2008; Chang et al. 2009). Therefore, the ETO rocks and the well-lithified Miocene sandstone blocks were both olistostromal products from the growing Hengchun accretionary wedge from retrowedge side. Since around 3.5 Ma the shortening of the Luzon forearc region caused intense thrust shearing of the lower and western parts of the forearc sequence containing the South China Sea fragments, forming the Lichi Mélange with penetrative shear fabrics (Chang et al. 2009).

The blueschist meta-ophiolitic tectonic blocks in the Yuli Belt, once ascertained as originated from the South China Sea, originated from deep part of the Manila subduction (Tsai et al. 2013; Chen et al. 2017b). These Yuli ophiolitic rocks went down the subduction channel after their formation around $15 \mathrm{Ma}$, and reached blueschist-facies conditions either before $\sim 9 \mathrm{Ma}$ or $\sim 5 \mathrm{Ma}$ (whether taking into account of apparent white mica ${ }^{40} \mathrm{Ar} /{ }^{39} \mathrm{Ar}$ cooling/formation ages or the garnet prograde growth ages from Sandmann et al. 2015, respectively; please refer to discussion in section 5.2). The blueschist rocks then detached from the subducting slab and rose up. Whether exhumation of the blueschist was continuous as suggested by petrophysical analysis of high-velocity zone extending from shallow depths beneath eastern Central Range to $\sim 50 \mathrm{~km}$ deep (Brown et al. 2015), or resided in mid-crustal level during early arc-continent collision and overprinted with greenschist-facies metamorphism is not yet clear; the $\sim 3$ Ma metamorphic zircon overgrowth ages (Yui et al. 2014) and the 4 Ma phlogopite age (Lo and Yui 1996) likely favor the latter scenario. During Quaternary time the whole eastern Central Range including the Yuli Belt underwent fast exhumation $\left(\sim 65^{\circ} \mathrm{C} \mathrm{Ma}^{-1}\right.$ or $\left.>4 \mathrm{~mm} \mathrm{yr}^{-1}\right)$ indicated by thermochronology data (Fuller et al. 2006; Lee et al. 2006b; Chen et al. 2017b).

A working tectonic model of the Taiwan arc-continent collision with emphasis on the incorporation of South China Sea ophiolitic materials into various parts of the mountain belt is proposed (Fig. 6). Formation of new South China Sea oceanic lithosphere for the area around and southeast (considering the direction and rate of convergence between the Eurasia and Philippines Sea plates) of the present Taiwan persisted until $\sim 15 \mathrm{Ma}$ as inferred from geochronological ages of ophiolitic igneous products (this study; Shao 2015; Hsieh et al. 2017) and seafloor magnetic anomaly interpretation (Yeh et al. 2010). The onset of Luzon Arc magmatism at $\sim 15 \mathrm{Ma}$ (Song and Lo 2002) suggests subduction of the South China Sea along the Manila Trench commenced immediately after (or simultaneously) with the last episodes of seafloor spreading. Contemporaneous with the arc volcanism was high-pressure metamorphism of the leading parts of the subducted South China Sea oceanic lithosphere (Fig. 6a), and simultaneous ophiolite incorporation along the trench interface into the accretionary wedge (cf. Dilek and Furnes 2014). Ophiolitic blocks in the Kenting Mélange were mostly scrapped-off from subducting South China Sea along the Manila Trench interface (Chang et al. 2003). Earlier equivalents of Kenting ophiolitic rocks were stacked deep within the accretionary wedge, and some were exhumed in the eastern retro-side then shed into the pelagic sediments in the Luzon forearc basin as the future Lichi Mélange matrix (Malavieille et al. 2016; Chen et al. 2017a), constituting the 

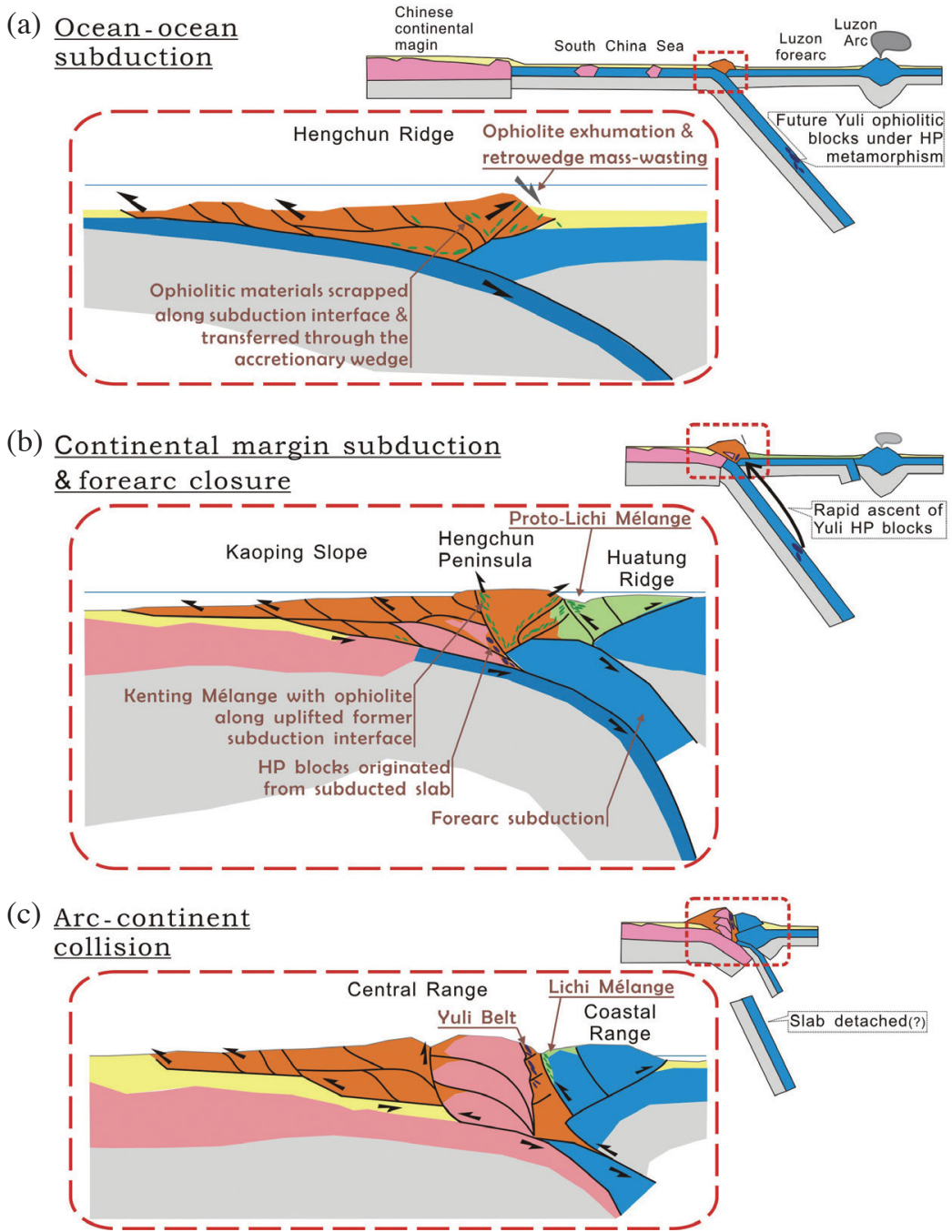

Fig. 6. Conceptual illustration of proposed tectonic model of Taiwan arc-continent collision. (a) During oceanic subduction stage, the future Yuli metabasites subducted to mantle depths, while at shallow crustal level fragments of South China Sea lithosphere were off-scraped and accreted to the accretionary wedge above the Manila Trench, in which some were back-thrust to the retrowedge and landslide into Luzon forearc. (b) When Chinese continental margin started entering the Manila Trench as the South China Sea was consumed, the original subduction interface was uplifted and exhumed as the Kenting Mélange; meanwhile increased compressional strain in the upper plate caused Luzon forearc subduction, forming the Lichi Mélange when forearc sediments were buttressed against the Luzon Arc, and the deeply-subducted Yuli blueschist ascended to mid-crust levels within the collisional mass. (c) Continued continental subduction and basal accretion led the Yuli blueschist together with other mid-crustal rocks to be exhumed along the eastern flank of the Central Range.

ophiolitic blocks now outcropping within the Lichi Mélange (Fig. 6a inset). Meanwhile the subducted South China Sea oceanic crust were under high-pressure metamorphism, and some of them started to ascend back to crustal level from maximum depths $\sim 45 \mathrm{~km}$ (Tsai et al. 2013; Baziotis et al. 2017; Fig. 6b). Timing of initial blueschist exhumation remains disputed as whether at around $9 \mathrm{Ma}$ indicated by the muscovite-phengite ${ }^{40} \mathrm{Ar} /{ }^{39} \mathrm{Ar}$ ages (Lo and Yui 1996; this study) or later than the garnet prograde growth age (5.1 \pm 1.7 Ma, Sandmann et al. 2015); this exhumation event was likely punctuated from the recent fast rock exhumation documented along the entire eastern flank of the Central Range (e.g., Fuller et al. 2006; Lee et al. 2006b) as evidenced by the greenschist-facies overprint and mineral overgrowth (Yui et al. 2014), plus the young phlogopite ${ }^{40} \mathrm{Ar} /{ }^{39} \mathrm{Ar}$ age as retrograde cooling (Lo and Yui 1996). These blueschist ophiolitic bodies are embedded in greenschist-facies deep-sea matrix, indicating mid-crustal mixture of in-situ tectonically-buried then basal accreted marine deposits and the rising HP metaophiolitic rocks during the early stages of the arc-continent collision (Fig. 6b inset). Later on the Yuli Belt rocks underwent rapid exhumation to surface during the advanced collision stage (Huang et al. 2006), concurrent to island-wide acceleration of rock uplift (Lee et al. 2015; Chen et al.2018). The Luzon forearc lithosphere of the Philippine Sea Plate is not yet identified in surface geology, suggesting complete 
underthrusting/subduction towards east beneath the Luzon Arc/Coastal Range (Fig. 6b; McIntosh et al. 2005; Shyu et al. 2011; Malavieille et al. 2016).

\section{CONCLUDING REMARKS}

Ophiolitic rocks as tectonic blocks in the Yuli Belt on the Eurasian side of the Taiwan collisional suture, as well as the Lichi Mélange on the Philippine Sea side, are all found to have formed at $\sim 15 \mathrm{Ma}$ based on zircon U-Pb ages supplemented by ${ }^{40} \mathrm{Ar} /{ }^{39} \mathrm{Ar}$ dating results. Such constraints on ages of protolith formation and crystallization indicate that the ophiolitic materials on both sides of the plate suture are remnants of South China Sea oceanic lithosphere, since the opening of the South China Sea persisted to 15 14 Ma while the oceanic lithosphere of the Philippine Sea Plate east and southeast of Taiwan is Eocene or older. These South China Sea ophiolites therefore serve as benchmarks in reconstructing the subduction and following mountain building processes of the active Taiwan orogeny. Ophiolitic blocks in the Kenting Mélange recorded tectonic off-scraping and accretion of South China Sea oceanic lithosphere during thrusting along the Manila subduction interface. Deeper equivalents of the Kenting ophiolitic rocks may have been exhumed along the eastern retrowedge of the accretionary prism and then shed into the Luzon forearc basin, whose closure during arc-continent collision led to formation of the Lichi Mélange. Some of the deeply-subducted (to $\sim 45 \mathrm{~km}$ depth) South China Sea rocks now constitute the blueschist blocks in the Yuli Belt after exhumation from high-pressure state to crustal depths and later to earth surface.

Acknowledgements The authors wish to thank T.-F. Yui, J. Malavieille, and the late B.-M. Jahn for extensive discussions on Taiwanese ophiolites. Editorial handling by R.-J. Rau, and constructive comments from C.-H. Tsai and an anonymous reviewer are deeply appreciated. This work was financially supported by Ministry of Science and Technology, Taiwan, R.O.C., under grant numbers: 106-2116-M-002-017 (C.-H. Lo), 107-2116-M-008-004, and 108-2628-M-008-002-MY2 (C.-T. Chen) and National Central University grants to C.-T. Chen.

\section{REFERENCES}

Baziotis, I., C.-H. Tsai, W. G. Ernst, B.-M. Jahn, and Y. lizuka, 2017: New $P-T$ constraints on the Tamayen glaucophane-bearing rocks, eastern Taiwan: Perple_X modelling results and geodynamic implications. $J$. Metamorph. Geol., 35, 35-54, doi: 10.1111/jmg.12218. [Link]

Beyssac, O., F. Negro, M. Simoes, Y. C. Chan, and Y. G. Chen, 2008: High-pressure metamorphism in Taiwan: From oceanic subduction to arc-continent colli- sion? Terr. Nova, 20, 118-125, doi: 10.1111/j.13653121.2008.00796.x. [Link]

Briais, A., P. Patriat, and P. Tapponnier, 1993: Updated interpretation of magnetic anomalies and seafloor spreading stages in the South China Sea: Implications for the Tertiary tectonics of Southeast Asia. J. Geophys. Res., 98, 6299-6328, doi: 10.1029/92jb02280. [Link]

Brown, D., Y. -M. Wu, K. -F. Feng, W. -A. Chao, and H. -H. Huang, 2015: Imaging high-pressure rock exhumation in eastern Taiwan. Geology, 43, 651-654, doi: 10.1130/G36810.1. [Link]

Chang, C.-P., J. Angelier, and C. -Y. Huang, 2000: Origin and evolution of a mélange: The active plate boundary and suture zone of the Longitudinal Valley, Taiwan. Tectonophysics, 325, 43-62, doi: 10.1016/s00401951(00)00130-x. [Link]

Chang, C.-P., J. Angelier, C.-Y. Huang, and C.-S. Liu, 2001: Structural evolution and significance of a mélange in a collision belt: The Lichi Mélange and the Taiwan arc-continent collision. Geol. Mag., 138, 633651, doi: 10.1017/S0016756801005970. [Link]

Chang, C.-P., J. Angelier, T.-Q. Lee, and C.-Y.Huang, 2003: From continental margin extension to collision orogen: Structural development and tectonic rotation of the Hengchun peninsula, southern Taiwan. Tectonophysics, 361, 61-82, doi: 10.1016/s0040-1951(02)00561-9. [Link]

Chang, C.-P., J. Angelier, and C.-Y. Huang, 2009: Evolution of Subductions Indicated by Mélanges in Taiwan. In: Lallemand, S. and F. Funiciello (Eds.), Subduction Zone Geodynamics, Springer, Berlin, Heidelberg, 207225, doi: 10.1007/978-3-540-87974-9_11. [Link]

Chen, C.-T., Y.-C. Chan, C.-Y. Lu, M. Simoes, and O. Beyssac, 2011: Nappe structure revealed by thermal constraints in the Taiwan metamorphic belt. Terr. Nova, 23, 85-91, doi: 10.1111/j.1365-3121.2011.00987.x. [Link]

Chen, C.-T., J.-C. Lee, Y.-C. Chan, C.-Y. Lu, and L. S.Y. Teng, 2014: Elucidating the geometry of the active Shanchiao Fault in the Taipei metropolis, northern Taiwan, and the reactivation relationship with preexisting orogen structures. Tectonics, 33, 2400-2418, doi: 10.1002/2013TC003502. [Link]

Chen, C.-T., Y.-C. Chan, C.-H. Lo, and C.-Y. Lu, 2016: Growth of mica porphyroblasts under low-grade metamorphism - A Taiwanese case using in-situ ${ }^{40} \mathrm{Ar} /{ }^{39} \mathrm{Ar}$ laser microprobe dating. J. Struct. Geol., 92, 1-11, doi: 10.1016/j.jsg.2016.09.005. [Link]

Chen, C.-T., Y.-C. Chan, C.-H. Lo, J. Malavieille, C.-Y. Lu, J.-T. Tang, and Y.-H. Lee, 2018: Basal accretion, a major mechanism for mountain building in Taiwan revealed in rock thermal history. J. Asian Earth Sci., 152, 80-90, doi: 10.1016/j.jseaes.2017.11.030. [Link]

Chen, W.-H., C.-Y. Huang, Y. Yan, Y. Dilek, D. Chen, 
M.-H. Wang, X. Zhang, Q. Lan, and M. Yu, 2017a: Stratigraphy and provenance of forearc sequences in the Lichi Mélange, Coastal Range: Geological records of the active Taiwan arc-continent collision. J. Geophys. Res., 122, 7408-7436, doi: 10.1002/2017JB014378. [Link]

Chen, W.-S., S.-L. Chung, H.-Y. Chou, Z. Zugeerbai, W.Y. Shao, and Y.-H. Lee, 2017b: A reinterpretation of the metamorphic Yuli belt: Evidence for a middle-late Miocene accretionary prism in eastern Taiwan. Tectonics, 36, 188-206, doi: 10.1002/2016TC004383. [Link]

Chi, W.-C., L. Chen, C.-S. Liu, and M. Brookfield, 2014: Development of arc-continent collision mélanges: Linking onshore geological and offshore geophysical observations of the Pliocene Lichi Mélange, southern Taiwan and northern Luzon arc, western Pacific. Tectonophysics, 636, 70-82, doi: 10.1016/j. tecto.2014.08.009. [Link]

Chi, W.-R., J. Namson, and J. Suppe, 1981: Stratigraphic record of plate interactions in the Coastal Range of eastern Taiwan. Mem. Geol. Soc. China, 4, 155-194.

Chiu, H.-Y., S.-L. Chung, F.-Y. Wu, D. Liu, Y.-H. Liang, I.-J. Lin, Y. Iizuka, L.-W. Xie, Y. Wang, and M.-F. $\mathrm{Chu}$, 2009: Zircon U-Pb and $\mathrm{Hf}$ isotopic constraints from eastern Transhimalayan batholiths on the precollisional magmatic and tectonic evolution in southern Tibet. Tectonophysics, 477, 3-19, doi: 10.1016/j.tecto.2009.02.034. [Link]

Chung, S.-L. and S.-S. Sun, 1992: A new genetic model for the East Taiwan Ophiolite and its implications for Dupal domains in the Northern Hemisphere. Earth Planet. Sci. Lett., 109, 133-145, doi: 10.1016/0012-821x(92)90079-b. [Link]

Deschamps, A., P. Monié, S. Lallemand, S.-K. Hsu, and K. Y. Yeh, 2000: Evidence for early Cretaceous oceanic crust trapped in the Philippine Sea plate. Earth Planet. Sci. Lett., 179, 503-516, doi: 10.1016/s0012821x(00)00136-9. [Link]

Dilek, Y. and H. Furnes, 2014: Ophiolites and their origins. Elements, 10, 93-100, doi: 10.2113/gselements.10.2.93. [Link]

Ernst, W. G., 2010: Subduction zone metamorphism - Pioneering contributions from the Alps. Int. Geol. Rev., 52, 1021-1039, doi: 10.1080/00206810903557852. [Link]

Fuller, C. W., S. D. Willett, D. Fisher, and C.-Y. Lu, 2006: A thermomechanical wedge model of Taiwan constrained by fission-track thermochronometry. Tectonophysics, 425, 1-24, doi: 10.1016/j.tecto.2006.05.018. [Link]

Halama, R., M. Konrad-Schmolke, M. Sudo, H. R. Marschall, and M. Wiedenbeck, 2014: Effects of fluid-rock interaction on ${ }^{40} \mathrm{Ar} /{ }^{39} \mathrm{Ar}$ geochronology in high-pressure rocks (Sesia-Lanzo Zone, Western
Alps). Geochim. Cosmochim. Acta, 126, 475-494, doi: 10.1016/j.gca.2013.10.023. [Link]

Harlow, G. E., 1994: Jadeitites, albitites and related rocks from the Motagua Fault Zone, Guatemala. $J$. Metamorph. Geol., 12, 49-68, doi: 10.1111/j.15251314.1994.tb00003.x. [Link]

Harrison, T. M., J. Célérier, A. B. Aikman, J. Hermann, and M. T. Heizler, 2009: Diffusion of ${ }^{40} \mathrm{Ar}$ in muscovite. Geochim. Cosmochim. Acta, 73, 1039-1051, doi: 10.1016/j.gca.2008.09.038. [Link]

Hsieh, R. B.-J., J. G. Shellnutt, and M.-W. Yeh, 2017: Age and tectonic setting of the East Taiwan Ophiolite: Implications for the growth and development of the South China Sea. Geol. Mag., 154, 441-455, doi: 10.1017/ S0016756816000054. [Link]

Huang, C.-Y., P. B. Yuan, and S.-J. Tsao, 2006: Temporal and spatial records of active arc-continent collision in Taiwan: A synthesis. Geol. Soc. Am. Bull., 118, 274288, doi: 10.1130/B25527.1. [Link]

Huang, C.-Y., C.-W. Chien, B. Yao, and C.-P. Chang, 2008: The Lichi Mélange: A collision mélange formation along early arcward backthrusts during forearc basin closure, Taiwan arc-continent collision. In: Draut, A. E., P. D. Clift, and D. W. Scholl (Eds.), Formation and Applications of the Sedimentary Record in Arc Collision Zones, GSA Special Papers, Volume 436, Geological Society of America, 127-154, doi: 10.1130/2008.2436(06). [Link]

Huang, C.-Y., W.-H. Chen, M.-H. Wang, C.-T. Lin, S. Yang, X. Li, M. Yu, X. Zhao, K.-M. Yang, C.-S. Liu, Y.-H. Hsieh, and R. Harris, 2018: Juxtaposed sequence stratigraphy, temporal-spatial variations of sedimentation and development of modern-forming forearc Lichi Mélange in North Luzon Trough forearc basin onshore and offshore eastern Taiwan: An overview. Earth-Sci. Rev., 182, 102-140, doi: 10.1016/j.earscirev.2018.01.015. [Link]

Huang, T.-C., M.-P. Chen, and W.-R. Chi, 1979: Calcareous nannofossils from the red shale of the ophiolitemélange complex, eastern Taiwan. Mem. Geol. Soc. China, 3, 131-138.

Itaya, T. and T. Tsujimori, 2015: White mica K-Ar geochronology of Sanbagawa eclogites from Southwest Japan: Implications for deformation-controlled K-Ar closure temperature. Int. Geol. Rev., 57, 1014-1022, doi: 10.1080/00206814.2014.973915. [Link]

Jahn, B.-M., 1986: Mid-ocean ridge or marginal basin origin of the East Taiwan Ophiolite: Chemical and isotopic evidence. Contrib. Mineral. Petrol., 92, 194-206, doi: 10.1007/bf00375293. [Link]

Jahn, B.-M., J.-G. Liou, and H. Nagasawa, 1981: High-pressure metamorphic rocks of Taiwan: REE geochemistry, $\mathrm{Rb}-\mathrm{Sr}$ ages and tectonic implications. Mem. Geol. Soc. China, 4, 497-520. 
Juan, V. C., H.-J. Lo, and C.-H. Chen, 1980: Genetic relationships and the emplacement of the exotic basic rocks enclosed in the Lichi mélange, east Coastal Range, Taiwan. Proc. Geol. Soc. China, 23, 56-68.

Karig, D. E., J. C. Ingle, A. H. Bouma, C. H. Ellis, N. Haile, I. Koizumi, H. Y. Ling, I. MacGregor, J. C. Moore, H. Ujiie, T. Watanabe, S. M. White, and M. Yasui, 1975: Initial Reports of the Deep Sea Drilling Project, 31, U.S. Government Printing Office, Washington, D.C., 972 pp, doi: 10.2973/dsdp.proc.31.1975. [Link]

Keyser, W., C.-H. Tsai, Y. Iizuka, R. Oberhänsli, and W. G. Ernst, 2016: High-pressure metamorphism in the Chinshuichi area, Yuli belt, eastern Taiwan. Tectonophysics, 692, 191-202, doi: 10.1016/j.tecto.2015.09.012. [Link]

Lai, Y.-M., S.-R. Song, C.-H. Lo, T.-H. Lin, M.-F. Chu, and S.-L. Chung, 2017: Age, geochemical and isotopic variations in volcanic rocks from the Coastal Range of Taiwan: Implications for magma generation in the Northern Luzon Arc. Lithos, 272-273, 92-115, doi: 10.1016/j.lithos.2016.11.012. [Link]

Lan, C.-H., 2011: Metamorphic petrogenesis and wholerock geochemistry of tectonic blocks in the Wanjung Area, Eastern Taiwan. Master Thesis, National Dong Hwa University, Hualien, Taiwan, 174 pp.

Lan, C.-Y. and J. G. Liou, 1984: Mineral Chemistry of metamorphosed oceanrocks in the Yuli belt of the Tananao schist, Taiwan. Memoir of Geological Society of China, 6, 153-179.

Lee, J.-Y., K. Marti, J. P. Severinghaus, K. Kawamura, H.S. Yoo, J. B. Lee, and J. S. Kim, 2006a: A redetermination of the isotopic abundances of atmospheric Ar. Geochim. Cosmochim. Acta, 70, 4507-4512, doi: 10.1016/j.gca.2006.06.1563. [Link]

Lee, Y.-H., C.-C. Chen, T.-K. Liu, H.-C. Ho, H.-Y. Lu, and W. Lo, 2006b: Mountain building mechanisms in the southern Central Range of the Taiwan orogenic belt - From accretionary wedge deformation to arc-continental collision. Earth Planet. Sci. Lett., 252, 413-422, doi: 10.1016/j.eps1.2006.09.047. [Link]

Lee, Y.-H., T. Byrne, W.-H. Wang, W. Lo, R.-J. Rau, and H.-Y. Lu, 2015: Simultaneous mountain building in the Taiwan orogenic belt. Geology, 43, 451-454, doi: 10.1130/G36373.1. [Link]

Lin, A. T., A. B. Watts, and S. P. Hesselbo, 2003: Cenozoic stratigraphy and subsidence history of the South China Sea margin in the Taiwan region. Basin Res., 15, 453478, doi: 10.1046/j.1365-2117.2003.00215.x. [Link]

Lin, A. T., B. Yao, S.-K. Hsu, C.-S. Liu, and C.-Y. Huang, 2009: Tectonic features of the incipient arc-continent collision zone of Taiwan: Implications for seismicity. Tectonophysics, 479, 28-42, doi: 10.1016/j.tecto.2008.11.004. [Link]

Lin, M.-L., 1999: Litho-stratigraphy and structural geology of the Wanjung area, eastern Taiwan and their tectonic implications. J. Geol. Soc. China, 42, 247-267.

Liou, J.-G., 1981: Petrology of metamorphosed oceanic rocks in the Central Range of Taiwan. Mem. Geol. Soc. China, 4, 291-341.

Liou, J. G. and W. G. Ernst, 1979: Oceanic ridge metamorphism of the East Taiwan Ophiolite. Contrib. Mineral. Petrol., 68, 335-348, doi: 10.1007/bf00371555. [Link]

Lo, C.-H. and T.-F. Yui, 1996: ${ }^{40} \mathrm{Ar} /{ }^{39} \mathrm{Ar}$ dating of highpressure rocks in the Tananao basement complex, Taiwan. J. Geol. Soc. China, 39, 13-30.

Lo, C.-H., S.-L. Chung, T.-Y. Lee, and G. Wu, 2002: Age of the Emeishan flood magmatism and relations to Permian-Triassic boundary events. Earth Planet. Sci. Lett., 198, 449-458, doi: 10.1016/s0012-821x(02)00535-6. [Link]

Lu, C.-Y. and K.-J. Hsu, 1992: Tectonic evolution of the Taiwan mountain belt. Petrol. Geol. Taiwan, 27, 2146.

Malavieille, J. and G. Trullenque, 2009: Consequences of continental subduction on forearc basin and accretionary wedge deformation in SE Taiwan: Insights from analogue modeling. Tectonophysics, 466, 377-394, doi: 10.1016/j.tecto.2007.11.016. [Link]

Malavieille, J., S. E. Lallemand, S. Dominguez, A. Deschamps, C.-Y. Lu, C.-S. Liu, P. Schnuerle, J. Angelier, J. Y. Collot, B. Deffontaines, M. Fournier, S. K. Hsu, J. P. Le Formal, S. Y. Liu, J. C. Sibuet, N. Thareau, and F. Wang, 2002: Arc-continent collision in Taiwan: New marine observations and tectonic evolution. In: Byrne, T. B. and C.-S. Liu (Eds.), Geology and Geophysics of an Arc-Continent Collision, Taiwan, GSA Special Papers, Volume 358, Geological Society of America, 189-213, doi: 10.1130/0-8137-2358-2.187. [Link]

Malavieille, J., G. Molli, M. Genti, S. Dominguez, O. Beyssac, A. Taboada, A. Vitale-Brovarone, C.-Y. Lu, and C.-T. Chen, 2016: Formation of ophiolite-bearing tectono-sedimentary mélanges in accretionary wedges by gravity driven submarine erosion: Insights from analogue models and case studies. J. Geodyn., 100, 87103, doi: 10.1016/j.jog.2016.05.008. [Link]

McIntosh, K., Y. Nakamura, T.-K. Wang, R.-C. Shih, A. Chen, and C.-S. Liu, 2005: Crustal-scale seismic profiles across Taiwan and the western Philippine Sea. Tectonophysics, 401, 23-54, doi: 10.1016/j.tecto.2005.02.015. [Link]

McIntosh, K., H. van Avendonk, L. Lavier, W. R. Lester, D. Eakin, F. Wu, C.-S. Liu, and C.-S. Lee, 2013: Inversion of a hyper-extended rifted margin in the southern Central Range of Taiwan. Geology, 41, 871-874, doi: 10.1130/G34402.1. [Link]

Odin, G. S., 1982: Interlaboratory standards for dating purposes. Numerical Dating in Stratigraphy, Part 1, John Wiley \& Sons, Chichester, United Kingdom, 123-148. 
Page, B. M. and J. Suppe, 1981: The Pliocene Lichi melange of Taiwan: Its plate-tectonic and olistostromal origin. Am. J. Sci., 281, 193-227, doi: 10.2475/ajs.281.3.193. [Link]

Pan, G., L. Wang, R. Li, S. Yuan, W. Ji, F. Yin, W. Zhang, and B. Wang, 2012: Tectonic evolution of the Qinghai-Tibet Plateau. J. Asian Earth Sci., 53, 3-14, doi: 10.1016/j.jseaes.2011.12.018. [Link]

Putlitz, B., M. A. Cosca, and J. C. Schumacher, 2005: Prograde mica ${ }^{40} \mathrm{Ar} /{ }^{39} \mathrm{Ar}$ growth ages recorded in high pressure rocks (Syros, Cyclades, Greece). Chem. Geol., 214, 79-98, doi: 10.1016/j.chemgeo.2004.08.056. [Link]

Queano, K. L., J. R. Ali, J. Milsom, J. C. Aitchison, and M. Pubellier, 2007: North Luzon and the Philippine Sea Plate motion model: Insights following paleomagnetic, structural, and age-dating investigations. J. Geophys. Res., 112, B05101, doi: 10.1029/2006JB004506. [Link]

Renne, P. R., R. Mundil, G. Balco, K. Min, and K. R. Ludwig, 2010: Joint determination of ${ }^{40} \mathrm{~K}$ decay constants and ${ }^{40} \mathrm{Ar} * / 40 \mathrm{~K}$ for the Fish Canyon sanidine standard, and improved accuracy for ${ }^{40} \mathrm{Ar} /{ }^{39} \mathrm{Ar}$ geochronology. Geochim. Cosmochim. Acta, 74, 5349-5367, doi: 10.1016/j.gca.2010.06.017. [Link]

Renne, P. R., G. Balco, K. R. Ludwig, R. Mundil, and K. Min, 2011: Response to the comment by W.H. Schwarz et al. on "Joint determination of ${ }^{40} \mathrm{~K}$ decay constants and ${ }^{40} \mathrm{Ar} * /{ }^{40} \mathrm{~K}$ for the Fish Canyon sanidine standard, and improved accuracy for ${ }^{40} \mathrm{Ar} /{ }^{39} \mathrm{Ar}$ geochronology" by P.R. Renne et al. (2010). Geochim. Cosmochim. Acta, 75, 5097-5100, doi: 10.1016/j.gca.2011.06.021. [Link]

Rubatto, D., 2002: Zircon trace element geochemistry: Partitioning with garnet and the link between $\mathrm{U}-\mathrm{Pb}$ ages and metamorphism. Chem. Geol., 184, 123-138, doi: 10.1016/s0009-2541(01)00355-2. [Link]

Ruffet, G., G. Gruau, M. Ballèvre, G. Féraud, and P. Philippot, 1997: $\mathrm{Rb}-\mathrm{Sr}$ and ${ }^{40} \mathrm{Ar} /{ }^{39} \mathrm{Ar}$ laser probe dating of high-pressure phengites from the Sesia zone (Western Alps): Underscoring of excess argon and new age constraints on the high-pressure metamorphism. Chem. Geol., 141, 1-18, doi: 10.1016/s0009-2541(97)000521. [Link]

Sandmann, S., T. J. Nagel, N. Froitzheim, K. Ustaszewski, and C. Münker, 2015: Late Miocene to early Pliocene blueschist from Taiwan and its exhumation via forearc extraction. Terr. Nova, 27, 285-291, doi: 10.1111/ ter.12158. [Link]

Shao, W.-Y., 2015: Zircon U-Pb and Hf isotope constraints on the petrogenesis of igneous rocks in eastern Taiwan. Ph.D. Thesis, National Taiwan University, Taipei City, Taiwan, 287 pp, doi: 10.6342/NTU.2015.01013. [Link]
Shellnutt, J. G. and R. B.-J. Hsieh, 2016: Mantle potential temperature estimates of basalt from the East Taiwan Ophiolite. Terr. Atmos. Ocean. Sci., 27, 853-863, doi: 10.3319/TAO.2016.05.24.01(TT). [Link]

Shyu, J. B. H., K. Sieh, and Y.-G. Chen, 2005: Tandem suturing and disarticulation of the Taiwan orogen revealed by its neotectonic elements. Earth Planet. Sci. Lett., 233, 167-177, doi: 10.1016/j.eps1.2005.01.018. [Link]

Shyu, J. B. H., Y.-M. Wu, C.-H. Chang, and H.-H. Huang, 2011: Tectonic erosion and the removal of forearc lithosphere during arc-continent collision: Evidence from recent earthquake sequences and tomography results in eastern Taiwan. J. Asian Earth Sci., 42, 415-422, doi: 10.1016/j.jseaes.2011.05.015. [Link]

Sibuet, J.-C., S.-K. Hsu, X. Le Pichon, J.-P. Le Formal, D. Reed, G. Moore, and C.-S. Liu, 2002: East Asia plate tectonics since 15 Ma: Constraints from the Taiwan region. Tectonophysics, 344, 103-134, doi: 10.1016/ s0040-1951(01)00202-5. [Link]

Song, S.-R. and H.-J. Lo, 2002: Lithofacies of volcanic rocks in the central Coastal Range, eastern Taiwan: Implications for island arc evolution. J. Asian Earth Sci., 21, 23-38, doi: 10.1016/s1367-9120(02)00003-2. [Link]

Sun, C.-H., A. D. Smith, and C.-H. Chen, 1998: Nd$\mathrm{Sr}$ isotopic and geochemical evidence on the protoliths of exotic blocks in the Juisui area, Yuli belt, Taiwan. Int. Geol. Rev., 40, 1076-1087, doi: 10.1080/00206819809465255. [Link]

Sung, Q., 1991: Some characteristics of sedimentary blocks in the Lichi Mélange, Coastal Range, Taiwan. Spec. Publ. Cent. Geol. Surv., 5, 231-256.

Suppe, J., 1981: Mechanics of mountain-building and metamorphism in Taiwan.Mem. Geol.Soc.China, 4, 67-89.

Suppe, J., 1984: Kinematics of arc-continent collision, flipping of subduction, and back-arc spreading near Taiwan. Mem. Geol. Soc. China, 6, 21-33.

Suppe, J., J. G. Liou, and W. G. Ernst, 1981: Paleogeographic origins of the Miocene East Taiwan Ophiolite. Am. J. Sci., 281, 228-246, doi: 10.2475/ajs.281.3.228. [Link]

Taylor, B. and D. E. Hayes, 1983: Origin and history of the South China Sea basin. In: Hayes, D. E. (Ed.), The Tectonic and Geologic Evolution of Southeast Asian Seas and Islands: Part 2, Volume 27, American Geophysical Union, 23-56, doi: 10.1029/GM027p0023. [Link]

Teng, L. S., 1990: Geotectonic evolution of late Cenozoic arc-continent collision in Taiwan. Tectonophysics, 183, 57-76, doi: 10.1016/0040-1951(90)90188-e. [Link]

Teng, L. S., 1996: Extensional collapse of the northern Taiwan mountain belt. Geology, 24, 949-952, doi: 10.1130/0091-7613(1996)024<0949:ECOTNT>2.3. $\mathrm{CO} ; 2$. [Link] 
Tian, Z.-X., Y. Yan, C.-Y. Huang, X.-C. Zhang, H.-Q. Liu, M.-M. Yu, D. Yao, and Y. Dilek, 2019: Geochemistry and geochronology of the accreted mafic rocks from the Hengchun Peninsula, southern Taiwan: Origin and tectonic implications. J. Geophys. Res., 124, 24692491, doi: 10.1029/2018JB016562. [Link]

Tsai, C.-H., Y. Iizuka, and W. G. Ernst, 2013: Diverse mineral compositions, textures, and metamorphic P-T conditions of the glaucophane-bearing rocks in the Tamayen mélange, Yuli belt, eastern Taiwan. J. Asian Earth Sci., 63, 218-233, doi: 10.1016/j.jseaes.2012.09.019. [Link]

Tsujimori, T. and G. E. Harlow, 2012: Petrogenetic relationships between jadeitite and associated high-pressure and low-temperature metamorphic rocks in worldwide jadeitite localities: A review. Eur. J.Mineral., 24, 371390, doi: 10.1127/0935-1221/2012/0024-2193. [Link]

Wang, K.-L., Y.-M. Lo, S.-L. Chung, C.-H. Lo, S.-K. Hsu, H.-J. Yang, and R. Shinjo, 2012: Age and geochemical features of dredged basalts from offshore SW Taiwan: The coincidence of intra-plate magmatism with the spreading South China Sea. Terr. Atmos. Ocean. Sci., 23, 657-669, doi: 10.3319/TAO.2012.07.06.01(TT). [Link]

Wu, F. T., W.-T. Liang, J.-C. Lee, H. Benz, and A. Villasenor, 2009: A model for the termination of the Ryukyu subduction zone against Taiwan: A junction of collision, subduction/separation, and subduction boundaries. J. Geophys. Res., 114, B07404, doi: 10.1029/2008JB005950. [Link]

Xu, Z.-Q., Y. Dilek, J.-S. Yang, F.-H. Liang, F. Liu, D.Z. Ba, Z.-H. Cai, G.-W. Li, H.-W. Dong, and S.-C. Ji, 2015: Crustal structure of the Indus-Tsangpo suture zone and its ophiolites in southern Tibet. Gondwana Res., 27, 507-524, doi: 10.1016/j.gr.2014.08.001.
[Link]

Yang, T. F., J.-1. Tien, C.-H. Chen, T. Lee, and R. S. Punongbayan, 1995: Fission-track dating of volcanics in the northern part of the Taiwan-Luzon Arc: Eruption ages and evidence for crustal contamination. J. Southeast Asian Earth Sci., 11, 81-93, doi: 10.1016/07439547(94)00041-c. [Link]

Yeh, Y.-C., J.-C. Sibuet, S.-K. Hsu, and C.-S. Liu, 2010: Tectonic evolution of the Northeastern South China Sea from seismic interpretation. J. Geophys. Res., 115, B06103, doi: 10.1029/2009JB006354. [Link]

Yui, T.-F. and C.-H. Lo, 1989: High-pressure metamorphosed ophiolitic rocks from the Wanjung area, Taiwan. Proc. Geol. Soc. China, 32, 47-62.

Yui, T.-F., C.-Y.Lu, and C.-H.Lo, 1988: A speculative tectonic history of the Tananao Schist of Taiwan. Proc. Geol. Soc. China, 31, 7-17.

Yui, T.-F., K. Maki, C. Y. Lan, T. Hirata, H. T. Chu, Y. Kon, T. D. Yokoyama, B. M. Jahn, and W. G. Ernst, 2012: Detrital zircons from the Tananao metamorphic complex of Taiwan: Implications for sediment provenance and Mesozoic tectonics. Tectonophysics, 541543, 31-42, doi: 10.1016/j.tecto.2012.03.013. [Link]

Yui, T.-F., T. Usuki, C.-Y. Chen, A. Ishida, Y. Sano, K. Suga, Y. Iizuka, and C.-T. Chen, 2014: Dating thin zircon rims by NanoSIMS: The Fengtien nephrite (Taiwan) is the youngest jade on Earth. Int. Geol. Rev., 56, 1932-1944, doi: 10.1080/00206814.2014.972994. [Link]

Zhang, X., P. A. Cawood, C.-Y. Huang, Y. Wang, Y. Yan, M. Santosh, W. Chen, and M. Yu, 2016: From convergent plate margin to arc-continent collision: Formation of the Kenting Mélange, southern Taiwan. Gondwana Res., 38, 171-182, doi: 10.1016/j.gr.2015.11.010. [Link] 